\title{
SVÄTÝ JUR NEŠTICH - NEW INSIGHTS ON THE SETTLEMENT AND FORTIFICATION OF THE EARLY MEDIEVAL HILLFORT ${ }^{1}$
}

\author{
Peter Milo - Július Vavák - Michal Vágner - Michaela Prištáková - \\ Igor Murín - Tomáš Tencer
}

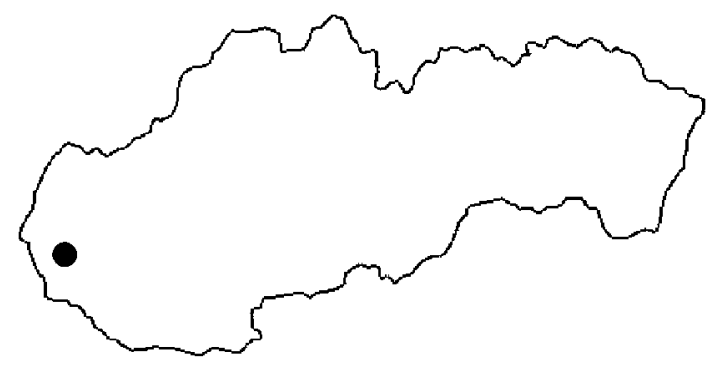

DOI: https://doi.org/10.31577/szausav.2020.67.5

Keywords: Svätý Jur, early medieval period, hillfort, fortification, geophysical survey, GPR, ERT, magnetometry

In literature, the hillfort in Svätý Jur is known as an important early medieval centre, dated back to the $9^{\text {th }}$ century, most notably to its second half. However, the first evidence of the use of the site in the Early medieval period comes from the $8^{\text {th }}$ century. Part of the monuments could also belong to the first half of the $10^{\text {th }}$ century. In addition to the central acropolis, which is defined by massive ramparts, the hillfort has two chronologically slightly younger baileys. Archaeological research here took place in the years 1957-1962 and restarted again in 2006. Nevertheless, information about the settlement density and its inner structure as well as the character of the fortification system are relatively modest. In this regard we tried to gain new knowledge by deploying a wide range of geophysical prospecting methods. Electrical Resistivity Tomography (ERT) and Georadar survey (GPR) measurements were carried out, focusing on the fortification elements of the hillfort. Within a third used method - magnetometry, we focused on the prospection of inner area of both outer baileys. On this count, it was possible to define the internal structure of the ramparts and identify some of the constructional elements of the wall, as well as to define the extent of the inhabited area and locate several settlement structures. From the methodological point of view, the comparison of geophysical data with the results of earlier archaeological research played an important role.

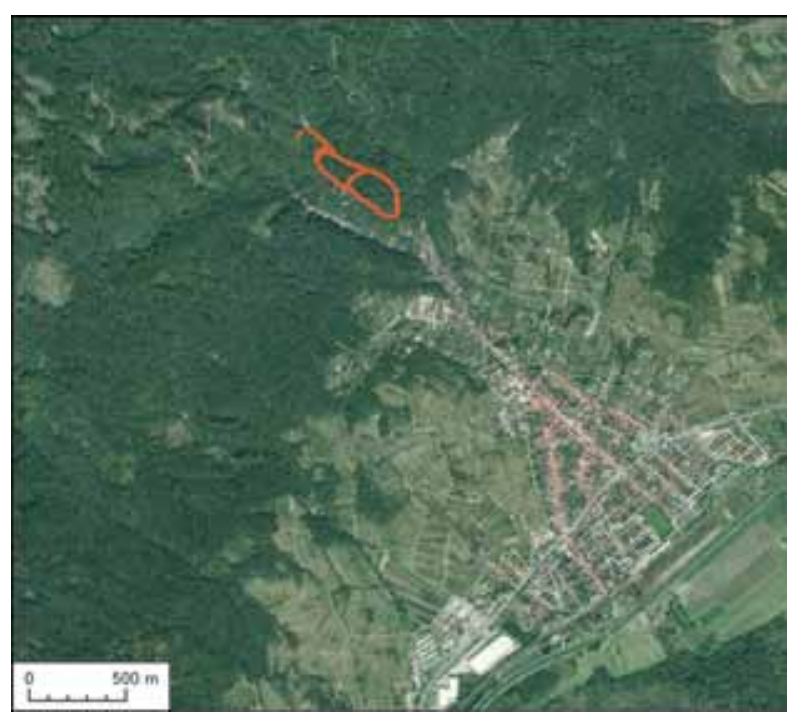

Fig. 1. Location of Svatý Jur-Neštich hillfort (background data - geoportal.sk). Red line - rampart.

\section{INTRODUCTION}

The Neštich hillfort is located in a wooded mountain spur of the Little Carpathians at the altitude of around $432 \mathrm{~m}$. The spur known to the locals as "Handrlák" or "Hradisko" rises above a former foothill village of Neštich (in german: "Neustift" - New village), which is now a part of Svätý Jur (Fig. 1).

The location is characterised by massive ramparts combined with ditches. The highest rampart encircles the approximately four hectares of the main castle area (in the shape of an ellipsis), which is in northwest enlarged by two horseshoe-shaped bailies one sized about 2.6 ha (bailey I.) and the other 1.9 ha (bailey II.) The full size of the fortified area is around $8.5 \mathrm{ha}$, which makes the hillfort at Sväty Jur one of medium to above-average sized locations of a similar type in

1 This publication is based on research supported by the Czech Science Foundation (GA CR) under Grant No. 18-16153S and public funds provided by Slovak Arts Council. 
Slovakia (Šalkovský 2015, 28, 29). Through archaeological records of dwellings, we can trace the settlement at the site back as far as to the Hallstatt period. Earlier settlement is documented by small artefacts from the La Tène, Roman and Migration periods. The most intensive use of the settlement took place during the early medieval period as evidenced by settlement objects and numerous archaeological artefacts found. Based on these findings we can confirm settlement activities from the $8^{\text {th }}$ to $10^{\text {th }}$ century. Later, in the $13^{\text {th }}$ and $14^{\text {th }}$ centuries, the location was used by local Hunt-Poznans (Hont-Pázmány), who are credited with the construction of the palace building and the cistern as well as with the reconstruction of the acropolis fortification - mainly the brick gate (the last mentioned: Vavák 2019b).

Several archaeological excavations of the hillfort already took place in the past. The most recent systematic field excavation has been going on since 2006. Due to the limited possibilities of archaeology, for example limited size of excavated area or financially exhausting and time-consuming research of the massive ramparts, new data must also be collected by other methods. One of those is a detailed geophysical survey, which can quickly and precisely identify subsurface structures of archaeological nature. One of the important factors is that it is non-destructive and leaves the investigated object unchanged for the purposes of further research.

The aim of this paper is to present the results of geophysical surveys, which took place at the location in 2018 and 2019, and to compare them with already known facts. The methods used here were ERT and GPR survey that focused on fortification elements of the hillfort and an areal magnetic survey which focused mainly on the interior space of both bailies. The primary task of the first two methods was to define the inner structure of the ramparts and to identify their individual structural elements. The magnetic survey focused on the localisation of areas with high possibility of settlement objects.

\section{ARCHAEOLOGICAL EXCAVATIONS AT THE HILLFORT}

The hillfort at Svätý Jur entered the awareness of the professional community in the 1920s thanks to the interest of J. Eisner $(1928,39 ; 1933,272)$ and Š. Janšák (1929, 1-4), who also carried out the geodetical survey. The site was dated back to the Slavic period due to the artefacts found. However, relevant knowledge of the settlement and its dating was only discovered during L'. Kraskovská research in 1957, 1958 and 1962 (Kraskovská 1963). Twenty strip probes and one specific cross-section of the acropolis wall were examined. The research brought light to the dating of the site, which was formerly based only on the limited amount of ceramics found. The research detected a Hallstatt period settlement for the first time in a form of a settlement construction, but more importantly also detected evidence of an early medieval settlement from the $9^{\text {th }}$ to $10^{\text {th }}$ century. According to L'. Kraskovská, the site served as a refuge for the population from a wide area and she characterises it as a significant location in the Great Moravian territory. A major contribution to the research was the detection of a high medieval period settlement from the $13^{\text {th }}-14^{\text {th }}$ century in which the palace was built. The brick stone gate as well as the stone cistern powered by a unique ceramic pipe were also examined.

In $1982 \mathrm{~K}$. Tomčíková led a rescue archaeological research mission in the form of monitoring the damage caused by the construction of an asphalt road (Tomčíková 1983). In the 1990s, the site and its surroundings were looting by some members of the public using metal detectors and the processing of available findings rekindled the interest in the site (Turčan 2000).

In 2006 the site was geodetically surveyed (E. Blažová and M. Bartík) and a systematic research was renewed by a Malokarpatské museum in Pezinok, which has been going on with short breaks until today. By 2019, 15 probes have been examined as part of this research. Mostly located in the acropolis, but to a lesser extent also in baileys I and II. Predominantly only settlement objects from the early medieval period were found. Importantly, this research verified the presence of finds dated back to $8^{\text {th }}$ century connected to the material culture of Avar Khaganate. The most important evidence of anthropogenic activities at the site can be dated to the second half of the $9^{\text {th }}$ century. If we consider the usage of location, then it may overlap into the first half of the $10^{\text {th }}$ century. Material evidence connected with crafting, presence of armed forces, but especially with common life were found at the site. The most important find at the site may be the discovery of a jeweller's workshop in acropolis in trench number XIV, which was examined thanks to the unique discovery of an Arab coin minted in 867. Evidence of crafting luxurious Great Moravian silver and golden jewellery/decorative objects (granulation, filigree), was also found in that probe and its surroundings. The crafts character is underlined especially by the findings of numerous crucibles and nozzle fragments. Glass inserts for jewellery/decorative objects are also unique, as well 


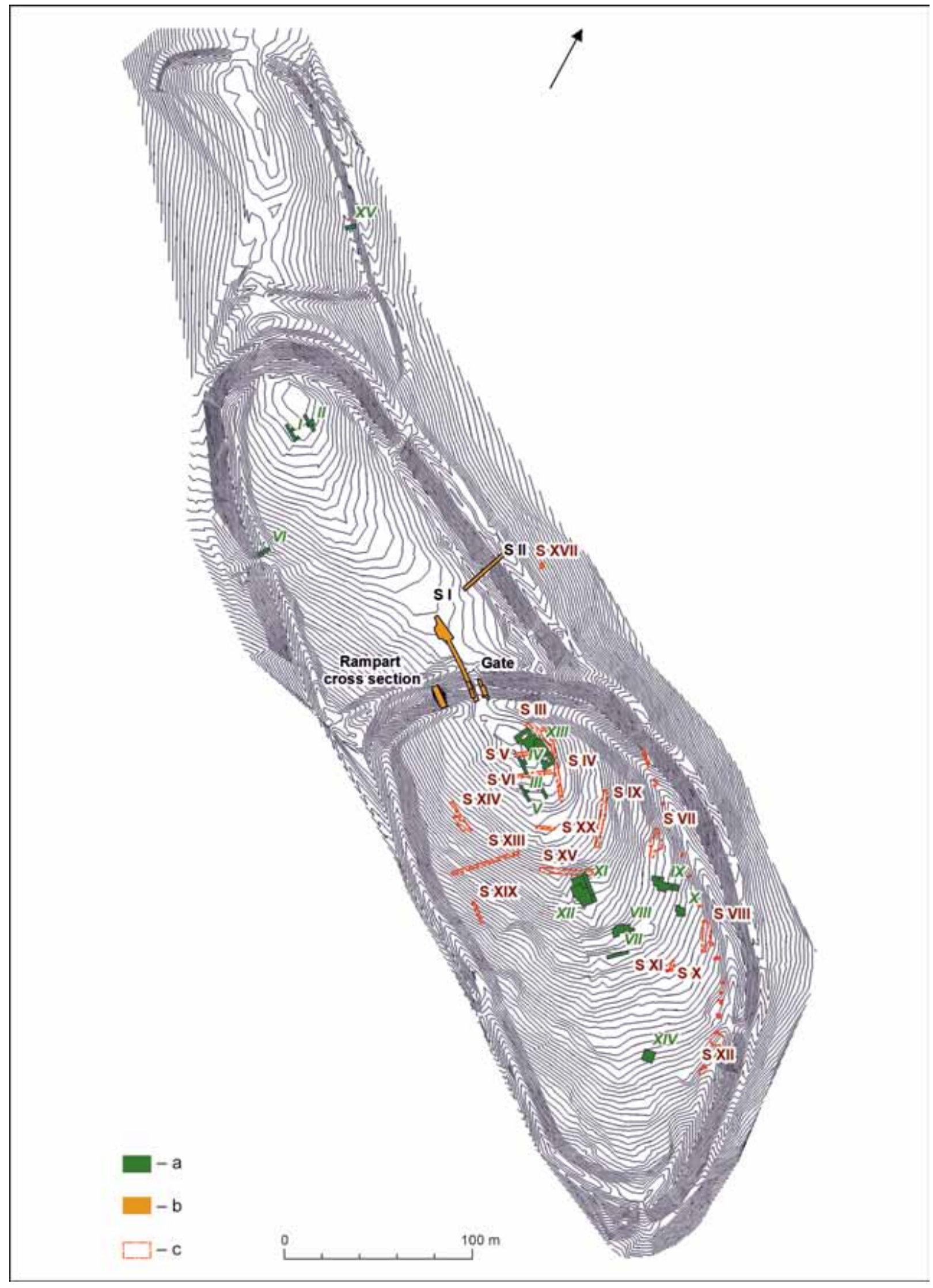

Fig. 2. Localisation of archaeological excavations at hillfort. Legend: a - excavation J. Vavák; b - excavation L. Kraskovská; c - excavation L'. Kraskovská (uncertain location). 
as findings of flat glass, fragments of glass containers and glass beads, which might provide evidence of local production. Important information was also contributed by a revision research of the palace at the acropolis site which was dated to the $13^{\text {th }}-14^{\text {th }}$ century as well as small objects found outside of the probes. Especially the evidence of human presence in different, formerly undocumented periods was found (La Téne and Roman periods; Vavák 2009; 2015; 2019a; 2019b). Overall, most of the archaeological activities at the site have been directed towards the main castle, while the baileys have been explored to a much lesser extent (Fig. 2). There was therefore ample justification for research activities on the hitherto unexplored parts of the hillfort.

\section{GEOPHYSICAL RESEARCH OF THE HILLFORT}

The history of archaeo-geophysical research of early medieval hillforts in Slovakia began in 1976 in which several surveys took place. At the hillfort in Pobedim a magnetometric survey was carried out ( $\mathrm{Lu}$ dikovský/Hašek/Obr 1978). A geoelectric resistance survey was carried out at the hillfort in Ducové (Gajdoš 1977, 116) and on another important site at Nitrianska Blatnica (Tirpák 1977, 120, 121). Sporadic exploratory actions continued but a significant increase in exploration activities only came at the beginning of the $21^{\text {st }}$ century. Complex geophysical research has been carried out at Majcichov and Pobedim hillforts (Ruttkay et al. 2006) together with research of significant parts of hillforts Bíňa (Ruttkay et al. 2006), Bojná (Pieta et al. 2011) and Pružina (Kováčová/Kovár/Milo 2015). The style and character of the rampart were documented together with its destruction, dispersion, and density of objects in both inner and outer part of the fortified area, which greatly contributed to better knowledge of these sites.

The first geophysical measurements of the hillfort at Svätý Jur were done in 2005 by J. Tirpák. In two segments he surveyed an area approximately 0.1 ha large through dipole electromagnetic and georadar profiling. He noted the presence of significant anomalies which he considers to be the remains of archaeological objects but does not describe them in more detail or interpret them (Tirpák 2005, 3, 4).

Further research at the site was carried out in 2013 by a team led by R. Pašteka et al. (2014) in which they carried out magnetic measurement as well as complementary georadar measurements. They researched the central part of bailey I through magnetometry. Within an area of approximately 0.5 ha they recorded the absence of anomalies that could be of an archaeological nature. It is worth pointing out that their conclusions were confirmed by research done in 2018 which also failed to find any significant traces of settlement in this part of the area. The identified linear structures were confirmed by georadar prospections. The authors claim that it might be remains of ramparts or ditches. On the one hand the 2018 research confirmed the given linear structure, but on the other hand due to exploration of a larger area this research ruled out the possibility that it could be an archaeological object. We can confirm that such anomalies also appear in different parts of the hillfort and are a manifestation of natural bedrock.

The aim of the geophysical prospection that took place in 2018 and 2019 was the detection of subsurface structures in an effort to locate areas with potential occurrence of archaeological situations in the area of the main castle and the bailey as well as to define the internal structure of the ramparts and to identify individual structural elements of the wall. Magnetometry was applied while solving the questions connected with the presence of recessed archaeological objects as well as the intensity of the settlement as a whole. Magnetic prospecting measures the intensity of the Earth's magnetic field in which anomalies indicating the presence of subsurface structures possessing different character are registered. The basis for the recognition of archaeological objects is their distinguishability from the surrounding environment. The most important role is played not by the absolute magnetic values of the fillings of these objects but rather by the contrast between the backfill of the object and the surrounding environment. Several factors are decisive for the intensity and shape of the magnetic anomaly and the associated measurement result but mainly the composition, preservation, size, shape, and depth of the prospect object. In the area of early medieval hillforts, we can expect positive results in localization of structures whose magnetization was created by a geomagnetic field under considerable temperature changes. These include e.g. fireplaces, furnaces, burnt layers, but also depots or separate iron items. Recessed objects secondarily filled with darker clays with organic residues and magnetic minerals are also well detectable. We can include various settlement pits, troughs, ditches, recessed huts and ideally also graves. Due to the forested and uneven terrain at the hillfort we decided to use fluxgate magnetometer Ferex (Förster, Germany) which is suitable for surveys in such an environment. The instrument 


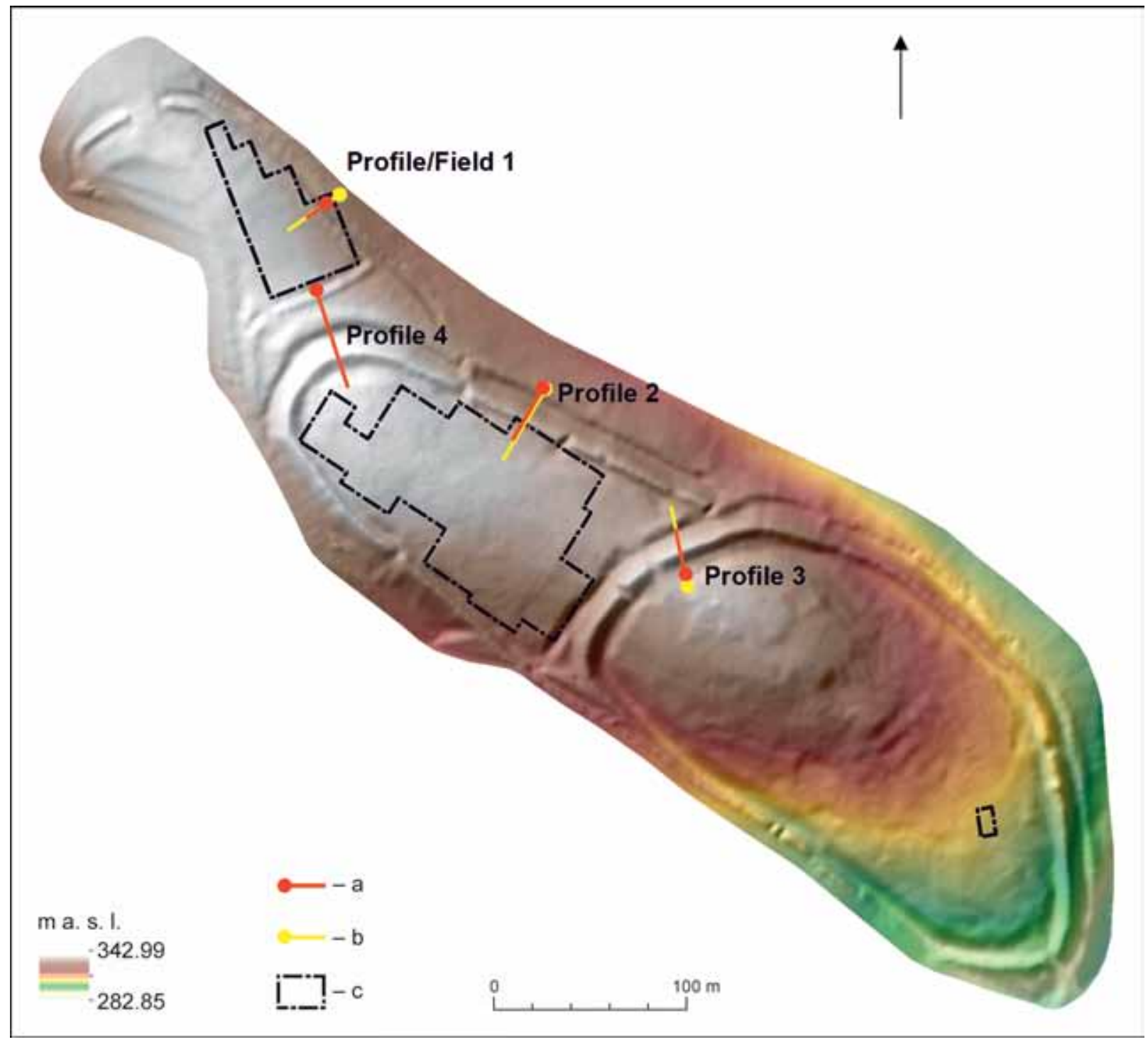

Fig. 3. Localisation of GRP and ERT profiles and area of the magnetic survey on the map of the hillfort. Legend: a - GPR profiles; $\mathrm{b}$ - ERT profiles; c - magnetometry.

is designed as a gradiometer for measuring the vertical gradient of the local magnetic field and can record magnetic field intensity values with an accuracy of $0.1 \mathrm{nT} / \mathrm{m}$. The horizontal distance between the four probes available to the device was $0.5 \mathrm{~m}$. The vertical distance between two sensors in each probe is $0.65 \mathrm{~m}$. The measurements were performed in a $0.25 \times 0.50 \mathrm{~m}$ grid. Collected data were processed in Foerster Dataload (Förster) program. Magdatashift software (Masaryk University) was used to correct erroneous measurement segments and the resulting magnetogram was constructed in Surfer (Golden software, inc.). A total of 3 polygons with an area of 1.4 ha were measured (Fig. 3).

For the purpose of georadar surveying, the X3M Ramac georadar (hereinafter referred to as GPR) from the Swedish company Geoscience $\mathrm{AB}$ Malå with two shielded antenna with a central frequency of 250 and $500 \mathrm{MHz}$ was used. The first antenna allows to reach a depth of about 6 meters under good physical conditions. The second used antenna has better horizontal and vertical resolution, but its depth range is limited to about $3 \mathrm{~m}$ below today's terrain. The GPR method works on the principle of monitoring changes in physical properties in the measured environment. The antenna moves along the measured profile and repeatedly sends a high-speed short-wave electromagnetic signal to the Earth's surface at predetermined intervals. If the transmitted signal encounters an anomaly - eg. a stone wall that has a different permittivity than the surrounding environment, it is reflected to the earth's surface where it is captured by the antenna receiver. The depth of the recorded anomaly was then calculated based on the 
time delay between the transmitted and the received signals. The result of the measurement are radarograms - vertical or horizontal time/depth cuts.

At the surveyed site, the GPR survey focused exclusively on the prospecting of the fortification elements presented in the hillfort and preserved in the form of ramparts and ditches. The aim of the prospection was to try to reveal the internal structure of the defunct fortifications, or to answer the question about the original extent and depth of the ditches. Four suitable sites were selected for prospection (Fig. 3). However, due to the complex topographic configuration of the terrain and the dense vegetation, GPR surveying was not possible in all four sections and the measurements were therefore limited to individual profiles in three cases. For area measurements with an antenna with a central frequency of $250 \mathrm{MHz}$ the distance between profiles was determined to be $0.5 \mathrm{~m}$. For measurements with an antenna with a central frequency of $500 \mathrm{MHz}$ the distance between lines was determined to be $0.25 \mathrm{~m}$. The interval of the measured points on the individual profiles was set to $0.1 \mathrm{~m}$ for both antennas. In the line perpendicular to the remains of the rampart, an altimetry survey (at $1 \mathrm{~m}$ interval) was performed on all four surveyed areas, which was subsequently used for processing the measured data for topographic corrections of vertical slices. Data collected from areal measurements were evaluated using ArchaeoFusion software (University of Arkansas), Easy 3D software (Geoscience AB Malå) and GPR Slice (Geophysical Archaeometry Laboratory). Horizontal time/depth slices were exported in raster form (JPEG) to ArcGIS (ESRI) where they were georeferenced to the corners of the polygons of interest. The identified anomalies were subsequently interpreted and digitalized into a vector plan. Vertical time/depth slices were processed using RadExplorer software (v. 1.42; Geoscience AB Malå) and vectorized in Adobe Illustrator CS6.

Lastly, electrical resistivity tomography (ERT) measurements were carried out at the hillfort. As in GPR measurements, their aim was to determine the internal structure of the defensive elements of the fort consisting of ramparts and ditches. By means of electrical resistivity methods we investigate the measured environment based on the differences in electrical resistivity $(\Omega \mathrm{m})$. The electrical resistance of rocks is influenced by factors such as mineral composition, porosity, and the degree of water saturation (Mareš et al. 1990). When measuring ERT, a larger number of electrodes are connected by a cable to the instrument. The measurement itself is carried out using four electrodes. Two of the electrodes are used as the source of electrical current that passes through the studied environment and the other pair of electrodes measure the ohmic resistance $(\Omega)$. By gradually increasing the distance between the electrodes, the electrical current from the supply electrodes will pass through a larger volume of the earth and reach greater depths. By repeating this procedure along the line at regular intervals of distances, a horizontal and vertical cross-sectional image of the measured environment is obtained, representing the distribution of the apparent electrical resistivity in each profile (Waddell/Fenwick/Barton 2009). When measuring, the result of the measured anomaly depends not only on the dimensions, shape, storage conditions, and electrical resistance of the buried inhomogeneity, but also on the appropriate choice of measurement configuration - electrode arrangement. Wenner's, Schlumberger's, and dipole-dipole configurations (Clark 1990) are those most used for archaeological purposes. These were also used in the measurements at the fort at Svätý Jur.

ERT measurements were performed on selected profiles of the previous georadar survey (Fig. 3). Together, three measurements were taken on P1, P2, and P3 areas with an electrode spacing of $1 \mathrm{~m}$ and a length of $36 \mathrm{~m}$ for P1, $47 \mathrm{~m}$ for P2, and $73 \mathrm{~m}$ for P3. For comparison, measurements were also performed in Wenner, Schlumberger and dipole - dipole configurations. The ARES apparatus (GF Instruments Brno) was used. Program RES2DINV (GEOTOMO, Malaysia) was used to process the collected data. The measured data was checked and any extreme (erroneous) values were removed. The measured values of the apparent resistivity were converted to the actual values of the resistivity by inversion. A topographic correction was applied and the resulting model representing the real distribution of the specific electrical resistance in the given profile was created.

\section{NEW FORTIFICATION KNOWLEDGE GAINED THROUGH GAINED THROUGH ERT AND GPR PROSPECTION}

The fortification of the site is still one of the most distinctive and best preserved in Slovakia. The height of the ramparts is still $11 \mathrm{~m}$ in some places. All the ramparts are surrounded by a ditch on the outer side and the inner side (Kraskovská 1963, 88; Vavák 2015, 4), while the outer side was designed to increase defence effectiveness and the inner side was created as a secondary element in the construction 


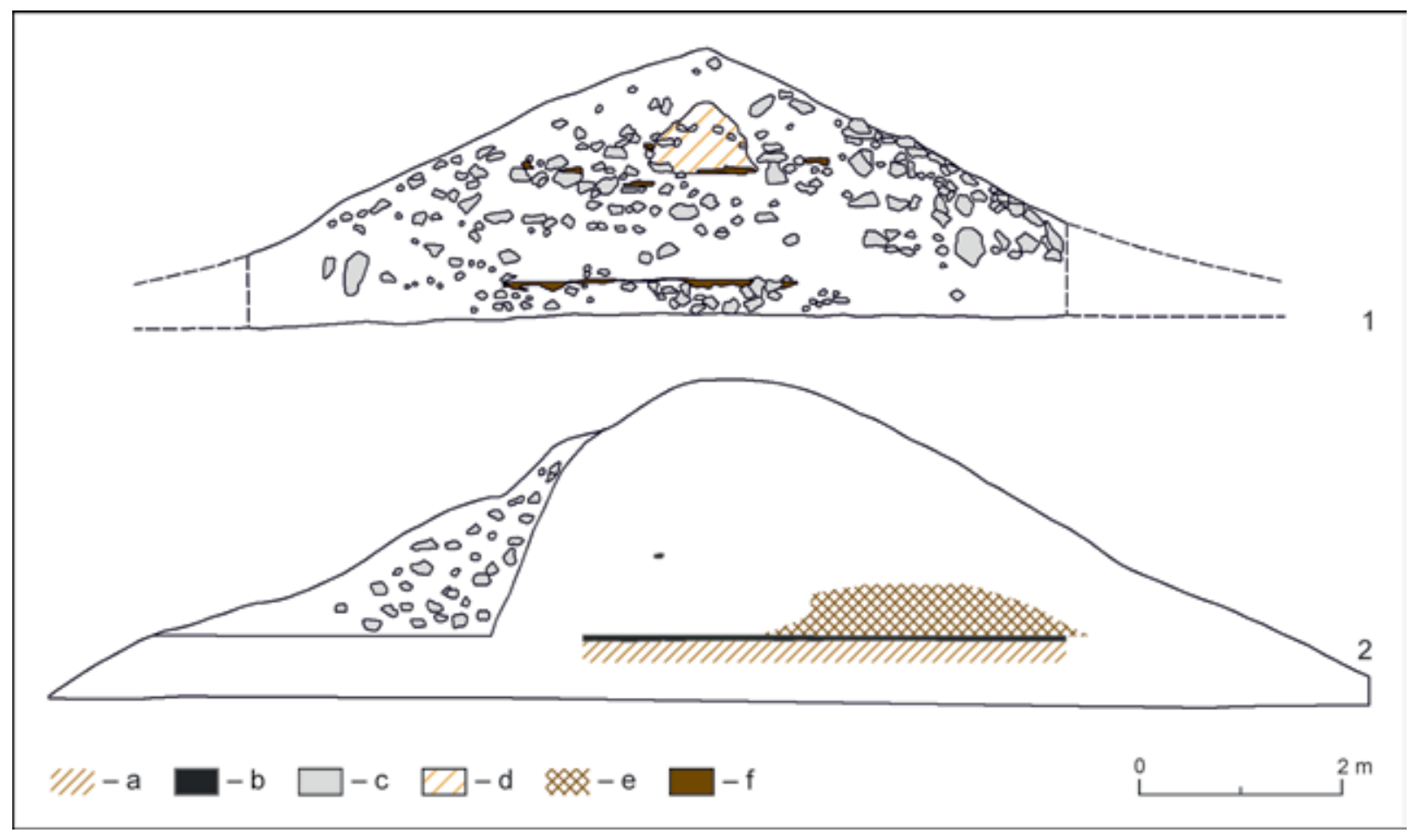

Fig. 4. Acropolis rampart. 1 - western sectional profile; 2 - eastern sectional profile (modified according to Kraskovská 1962; 1963, fig. 9). Legend: a - brown mixed soil; b-charcoal; c-stone; d - red burned soil; e-dark soil; f-burned wood.

of ramparts (Vavák 2009, 20). In 1957, 1958 and 1962 it was archaeologically examined by one probe of the rampart in bailey I and by two probes on a rampart in the main castle (Kraskovská 1963, 70). However, detailed documentation was only made in the case of the cut in the bailey and one of the probes in the main castle. The rampart at bailey II was archaeologically examined in 2018 and 2019 by trench (Vavák 2019a; $2019 b$, 58). It was found that the ramparts on the bailey have a different internal structure than the wall of the main castle and were built and attached to the acropolis in a slightly younger period (Kraskovská 1963, 91, 92; Vavák 2019b, 55-59).

\section{Fortification of the main castle}

A detailed description of the ramparts surrounding the acropolis of the hillfort is available from the research documentation of L. Kraskovská (Fig. 4). In the documented trench, on its western side at a depth of 50-150 cm, there was red-burnt clay at a width of $2.5 \mathrm{~m}$. In addition, there were remnants of a charred wooden construction. At a depth of $90 \mathrm{~cm}$ there was the rest of the burned wood and at $115 \mathrm{~cm}$ we found fragments of burnt beam with a length of $3 \mathrm{~m}$. The fractions did not lie in a line. Another beam with a thickness of 10 to $12 \mathrm{~cm}$ and a length of $290 \mathrm{~cm}$ lay at a depth of $225 \mathrm{~cm}$. Around the burnt clay and between the beams, there was dark ground mixed with larger stones that were probably poured there together with the soil. On the outside of the rampart, at the place where the beams ended, there were fallen stones, which can be interpreted as destruction of the front wall of the fortification. Charred wood and embers were also found on the eastern profile, at a depth of $175 \mathrm{~cm}$ and $250 \mathrm{~cm}$. Below was dark soil and clay (Kraskovská 1963, 86-88).

The documented archaeological situation suggests that the wall construction consisted of transverse beams 350-400 cm long, stacked in four layers $90 \mathrm{~cm}, 115 \mathrm{~cm}, 175 \mathrm{~cm}$ and 225-250 cm deep. This structure was covered with clay with an admixture of stones. Even though we were not able to find longitudinal beams, we can assume that there was a grate construction which was widely used during the early medieval period. On the outer side this construction was connected to the frontal stone wall which is indicated not only by captured situation but also by the number of stones in the destroyed part of the wall. Traces of fire indicate that the fortification was destroyed by a fire (Kraskovská 1963, 88, 91). 


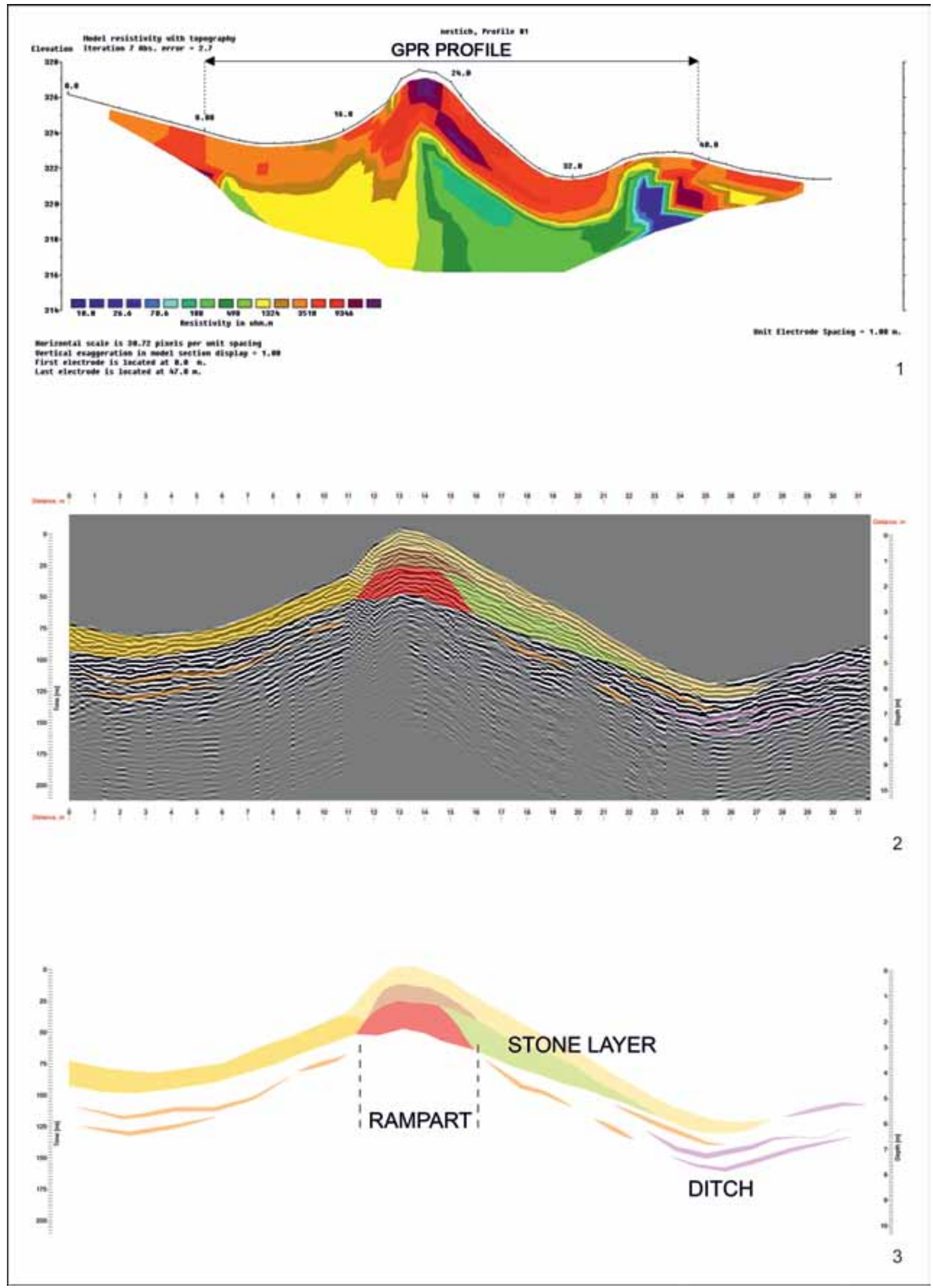

Fig. 5. Acropolis rampart (profile 3). 1 - the resulting ERT measurement profile (Schlumberger configuration); 2 - vertical time/depth GPR cut (500 MHz centre frequency antenna); 3 - interpretation plan of GPR profile. 
The information gathered by archaeological research are an important source for the interpretation of results gathered by geophysical measurement. Due to the complex topographic and surface situation only one profile was researched. This profile is situated in the north-western part of hillfort's acropolis and to the east of high medieval gate researched by L'. Kraskovská (Fig. 2; 3). It was perpendicularly oriented to the massive rampart body with an adjacent outer ditch. GPR research managed to identify a significant formation connected to the rampart body and to the lower part of the destroyed rampart (Fig 5). Horizontal layers in the rampart body illustrate the places where the original rampart is still preserved. Significant reflections were also documented in the ditches. They indicate that stone as a building material is significantly present in the rampart structure. Overall, however, we can say that the results of GPR prospection are not clearly conclusive and there are no significant differences between the intact part of the wall, its destruction and the ditch filling.

Electrical resistance measurements have a significantly higher informative value (Fig. 5). The whole rampart is manifested by higher resistance values, while in its central and frontal side there are anomalies consisting of material with the highest resistance values (above $10000 \Omega \mathrm{m}$ ) measured on the whole site. Such high values indicate a rich representation of stone as a building material. This observation fully corresponds with the archaeological research. The high electrical resistance values in the rampart body represent the stone filling in the rampart construction. The high electrical resistance values in the lower part of the frontal part of the rampart can be interpreted as a destroyed section of the frontal stone wall of the rampart. A high number of stones is also present in the filling of the frontal ditch which also exhibits a significantly higher resistance value. The filling of the ditch behind the wall does not exhibit such high values. It was filled by the destruction of the back wall of the rampart, which was not a stone wall. The survey results also show that both ditches reach into the subsoil. It is worth mentioning the low, not very prominent wall, located just in front of the outer ditch. Geophysical data shows that it is not only a randomly piled soil obtained by digging a ditch but an artificial fortification element. Its inner half shows lower resistance values and the outer side shows higher values interpreted as stone debris. However, archaeological research would have to be carried out for further information.

\section{Fortification of bailey I}

On the northwest side of the acropolis of the hillfort adjoins a rampart serving as protection for the hill area and as a boundary of bailey I. The rampart was not a part of the fortification from the beginning but was later attached to the main rampart. Its structure is known to us from the research of L. Kraskovská, who researched it using a single probe on the northern side. It is a pity that the finding situation was not recorded on the profiles but only in the horizontal plane once the rampart was removed (Fig. 6). The description of the finding situation shows that the rampart had a different construction than the rampart of the acropolis. On top of the rampart there is a $50 \mathrm{~cm}$ thick humus layer which goes down to $15 \mathrm{~cm}$ on the slopes. In addition, at the top there is a $20 \mathrm{~cm}$ thick and $80 \mathrm{~cm}$ wide layer of stones that stretched along the rampart and, according to the researcher, probably reinforced the soil in the fortification. At a depth of $85 \mathrm{~cm}$ perpendicular to the wall a series of stake pits began to appear. These gradually became smaller. Apparently, the stakes were driven into the slope. The dark filling of the stake pits contrasted with the yellow clay. At depths between 130 and $160 \mathrm{~cm}$ there was an ash layer in which there were early medieval ceramics and animal bones. At the wall of the rampart there was also daub, grey ash and stones. At a depth of $130 \mathrm{~cm}$ a second group of stake pits appeared but this time arranged in a triangular shape. Behind them there was a $110 \mathrm{~cm}$ wide and $15-20 \mathrm{~cm}$ thick layer of stones. In between layers of stake pits and below the second layer there was a layer of yellow soil reaching $200 \mathrm{~cm}$ deep. At a depth of $200-230 \mathrm{~cm}$ there was a $160 \mathrm{~cm}$ wide layer of stones. Only yellow clay was recorded deeper. From the inner side of the rampart a ditch of a conical shape was explored, reaching to a depth of $120 \mathrm{~cm}$ up to the bedrock. Its width at the top was $3.6 \mathrm{~m}$ and it was filled with dark alluvium (Kraskovská 1963, 82-85).

The finding situation shows that the fortification had two phases. The first phase consisted of a stake construction fixed with stones in two rows in a chessboard formation. The stakes fixed the beams and in between these was a clay filling which contained burned early medieval findings like daub, ceramics and bones. On the outer side, the stake construction was reinforced by a $110 \mathrm{~cm}$ thick stone wall. The whole rampart was approximately $3 \mathrm{~m}$ wide. The second phase was constructed after the destruction of 


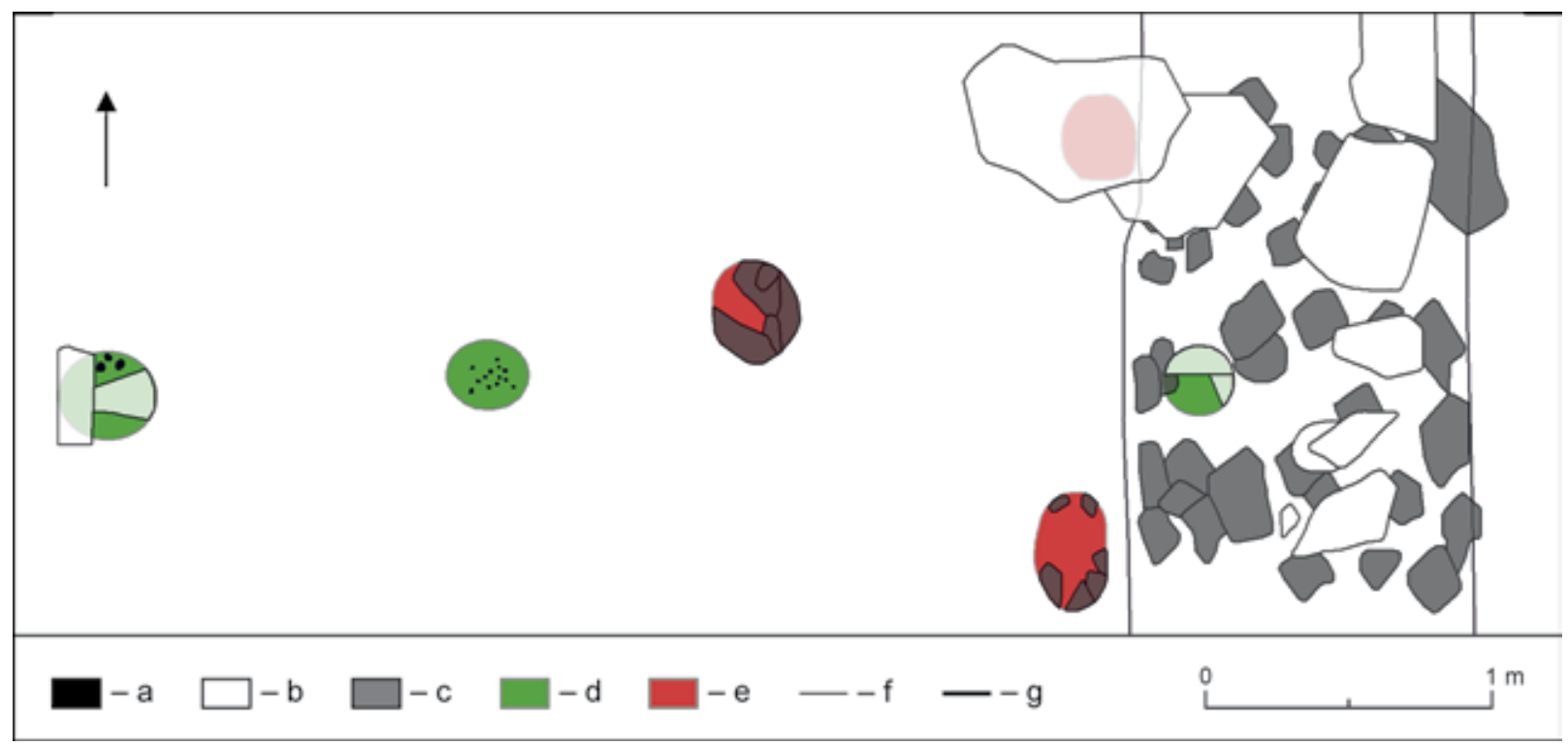

Fig. 6. Rampart at the bailey I. Ground plan recorded during archaeological excavation - older and younger phase of fortification (modified according to Kraskovská 1963, fig. 7; 8). Legend: a - charcoal; b - stone, younger phase; c - stone, older phase; $\mathrm{d}$ - stakehole, younger phase; e - stakehole, older phase; $\mathrm{f}$ - layer; $\mathrm{g}$ - trench.

the first phase. The surface was levelled, and a yellow clay rampart was built. In this phase the stakes were placed in four parallel rows. It can be assumed that other wooden elements covered with clay were placed between them. Again, there was a stone wall on the outer side. The thickness of the younger wall was $4.5-5 \mathrm{~m}$ so it was thicker than its predecessor (Kraskovská 1963, 84, 85, 91, 92).

In the framework of the geophysical survey of bailey I, questions were asked as to how will the fortification be reflected in GPR and ERT data, what will be the predicative value of the measurements and, above all, what will be the difference between those and the results collected at the rampart of the main castle. Most attention was paid to the P2 profile which passed through the rampart and the outer ditch on the northeast side of bailey I immediately west of the probe examined by L. Kraskovská (Fig. 2; 3).

The results of GPR measurements were negatively influenced by a considerable elevation of the terrain as well as by generally bad conditions such as wet and slippery surfaces. Under the uppermost layer in the place of the main rampart as well as a smaller rampart situated in front of a ditch from the outer side which appears to stretch across the entire profile, we managed to capture more distinct layers which are related to their internal composition (Fig. 7). However, based on the results of the GPR measurements, this composition cannot be further defined. We can only say that there is no significant anomaly on the radargram that would point to the presence of a well-preserved stone wall inside the rampart body. This conclusion corresponds with the above-stated results of the archaeological research. In addition, the expected assumption is that the ditch between the ramparts as well as the depression on the inner side of the fort were largely clogged with the material from the ramparts after the fortification ceased to function.

The ERT profile (Fig. 7) is slightly offset to the inner surface of the bailey compared to the georadar measurements. The results show a rampart with a ditch on the outside and a recess on the inside. The measured profile partially captures the smaller rampart in front of the outer ditch. The results of the measurements show that the ditches were used as a source of building material. Their depths reach down to the bedrock. For both ramparts, lower resistance values were measured on the inner side than on the outer side. The reason could be the fact that in the central and internal parts the original logging construction was recorded. The outer side of the ramparts with higher resistance values consists of material with higher stone content. Again, however, the resistance values are not significant. There is no significant increase in resistance values in the ditch in front of the rampart. It can be assumed that the stone material from the outer wall of the fortification is present in minimal quantities.

For reasons of the correlation of collected data, another profile was examined at the interface of baileys I and II. The course of profile 4 was situated over the remains of two ramparts (Fig. 2; 3). Through a rampart with an outer ditch which encircles the bailey as well as through a smaller rampart which 


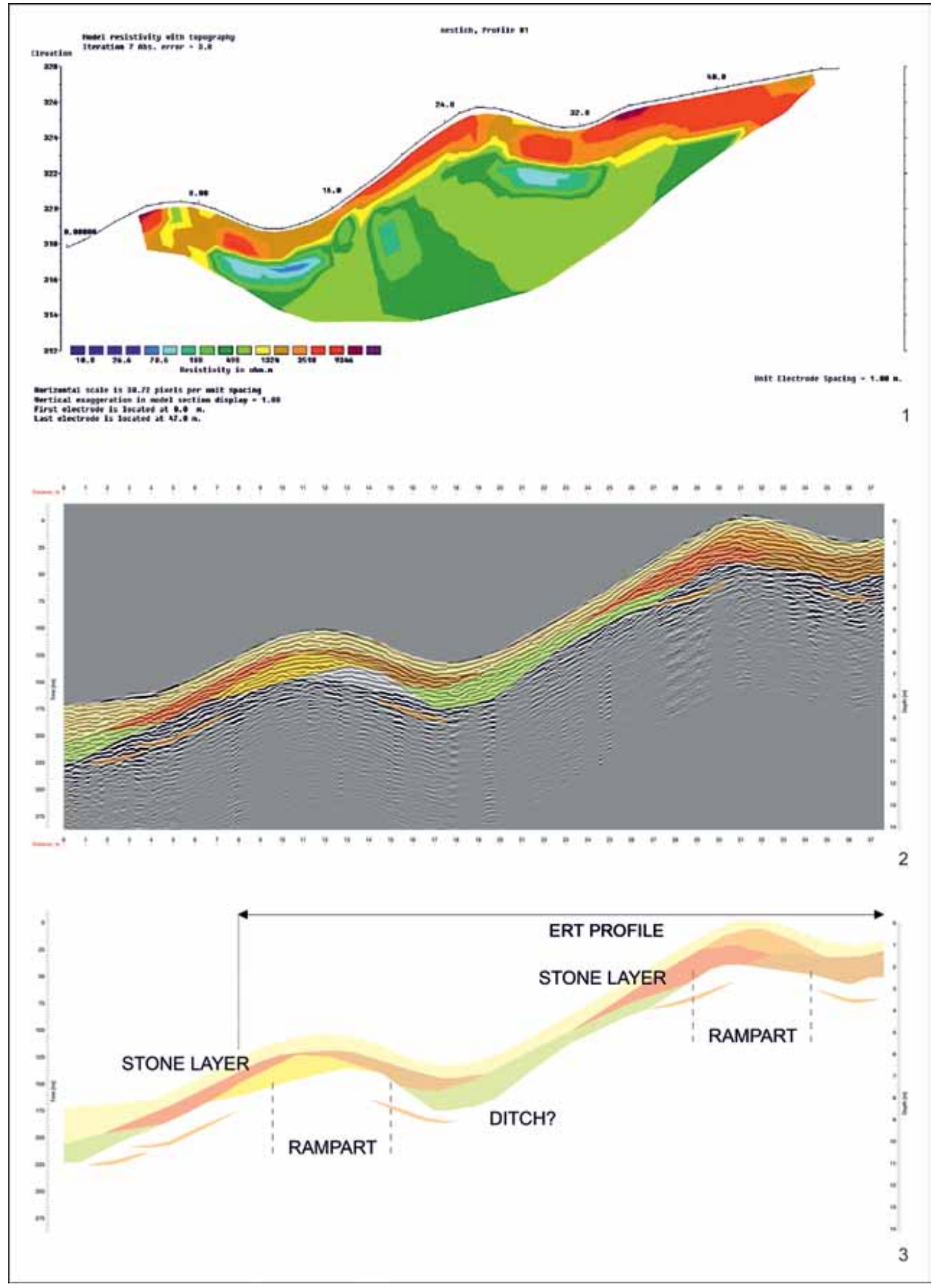

Fig. 7. Rampart at the bailey I., (profile 2). 1 - the resulting profile of ERT measurement (Schlumberger configuration); 2 - vertical time/depth GPR cut (500 MHz central frequency antenna); 3 - interpretation plan of GPR profile. 


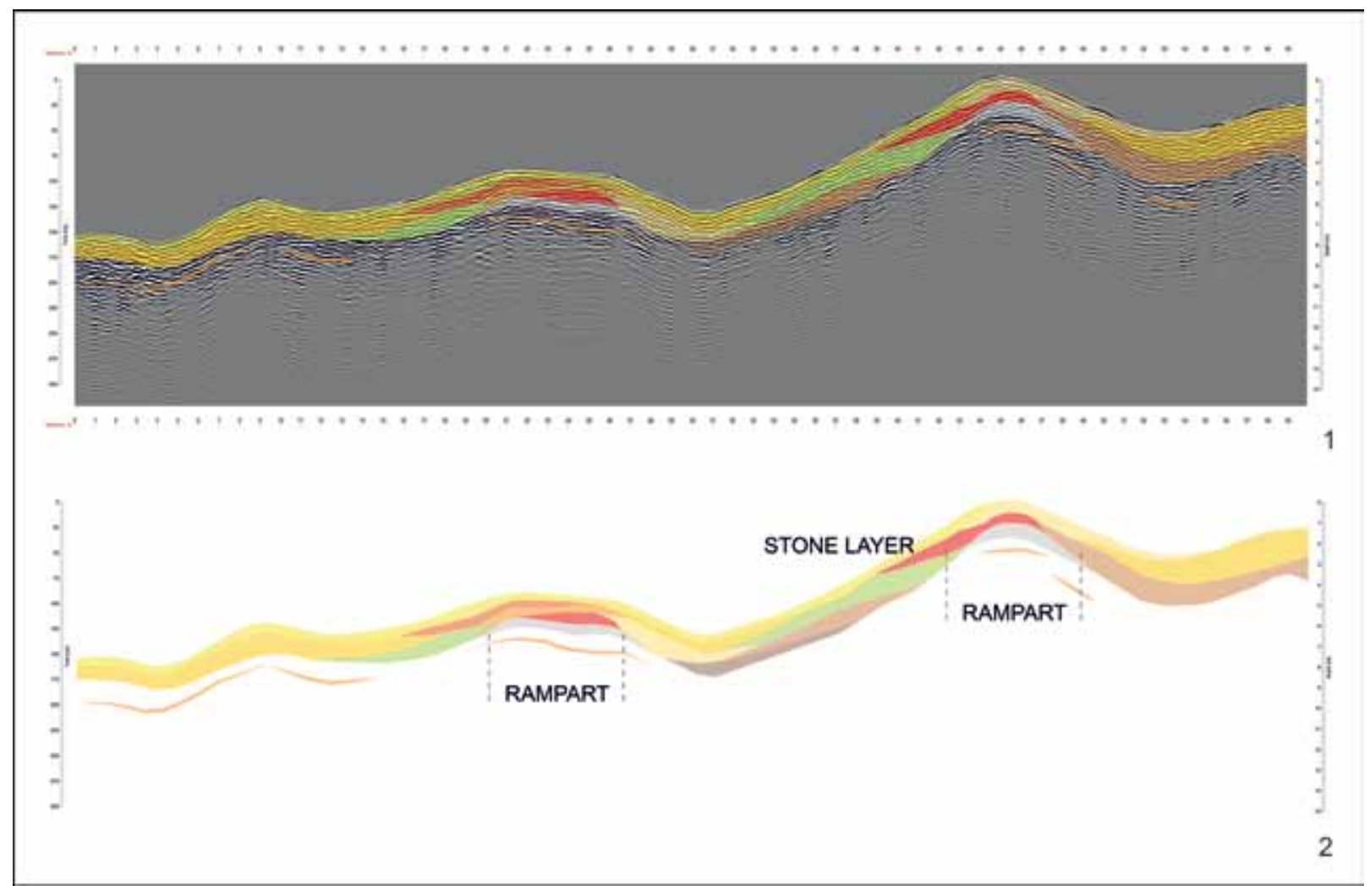

Fig. 8. Rampart at the bailey I. (profile 4). 1 - vertical time/depth GPR cut (500 MHz central frequency antenna); 2 - interpretation plan of GPR profile.

closes bailey II on the southeast side. The whole profile was $60 \mathrm{~m}$ long (Fig. 8). No ERT measurements were performed at this position for result comparison. On the final radargram we could point out several significant horizontal layers of which the most interesting one seems to be situated inside the rampart bodies. Here it is possible to distinguish several smaller layers which form the inner filling of both fortification elements. Within the main rampart of bailey I, there are several distinctive layers on its frontal side that are probably related to its destruction. No significant differences from the observations on profile 2 from the northern fortification segment were observed. As for the filled ditch located in front of the rampart, the depth of its original bottom can be estimated to be about $2 \mathrm{~m}$ from today's surface.

\section{Fortification of bailey II}

The rampart which earmarks bailey II is the smallest as well as the youngest. Its defensive value was low. It served to allocate the area of the hill above all symbolically, respectively for a purpose other than long-term defence. The geophysical survey (profile/area 1) was focused on the north-eastern segment of the rampart (Fig. 2; 3). An areal georadar survey conducted by two antennas with a central frequency of 250 and $500 \mathrm{MHz}$ revealed a greater number of anomalies that concentrate at two sites within the studied area (Fig. 9). The first cluster of anomalies can be observed in the centre of the area, i.e. in the course of the rampart itself. The identified anomalies cannot be accurately interpreted but it seems that they mark insignificant layers of stones and clay in the filling of the rampart. GPR prospection also managed to observe significant linear anomaly which stretches obliquely through the body of the rampart at a depth of about $2 \mathrm{~m}$ from the level of today's terrain. Due to the great depth and different orientation, however, we can assign a natural origin to the given structure. The second concentration of anomalies is located inside the encircled area. We have captured several inhomogeneities, however, it is impossible to interpret them any further. Partly they can be root systems of surrounding trees. In the area of the ditch on the north-eastern side of the observed area, the GPR prospection managed to capture only two anomalies, 


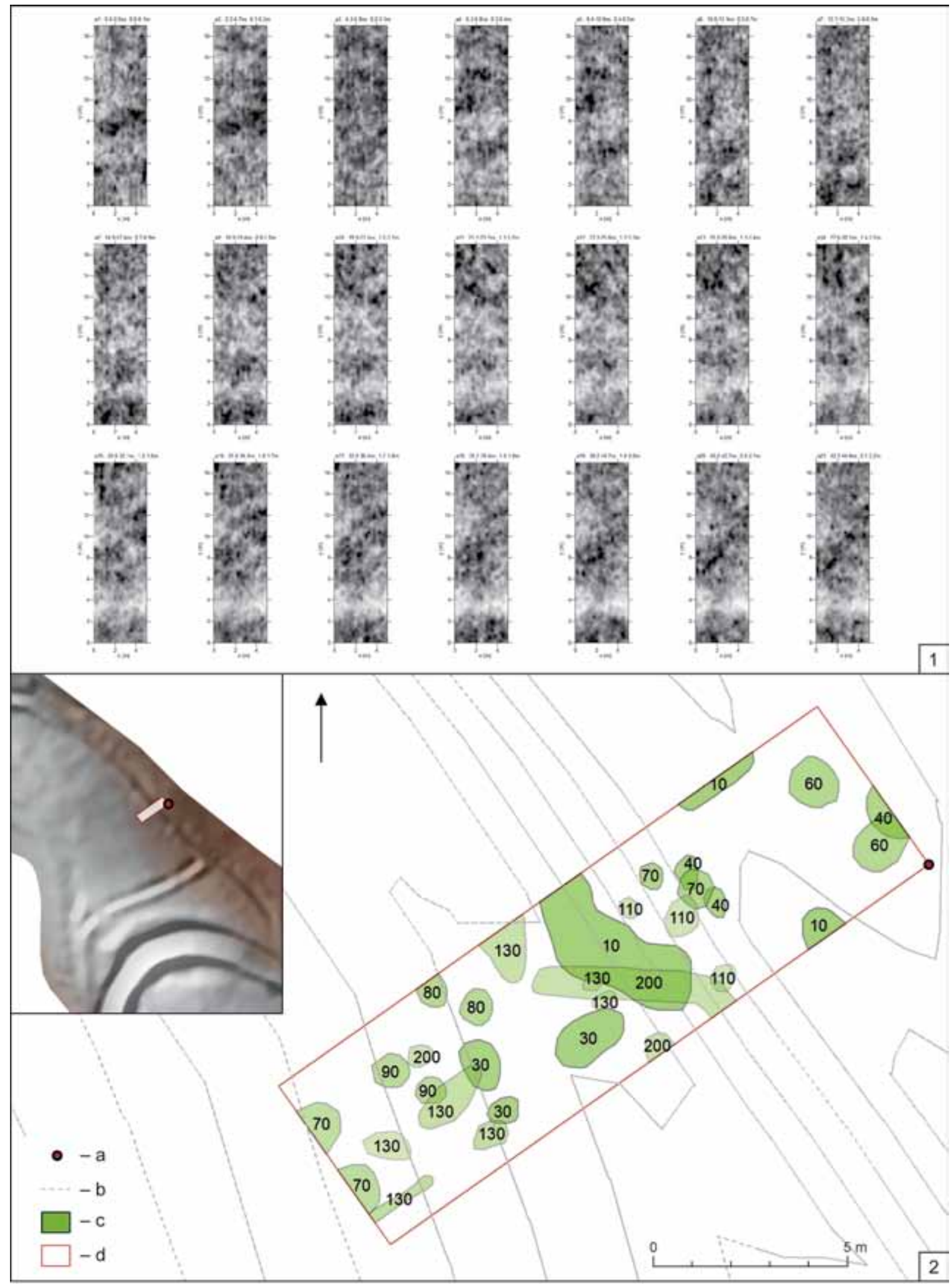

Fig. 9. Rampart at the bailey II. (area 1). 1 - resulting horizontal time/depth slices obtained by measuring with an antenna with a central frequency of $500 \mathrm{MHz}$ (created in GPR Slice); 2 - interpretation plan of the measured data. Legend: $\mathrm{a}$ - start; $\mathrm{b}$ - contours; c - anomalies; d - GPR survey. 


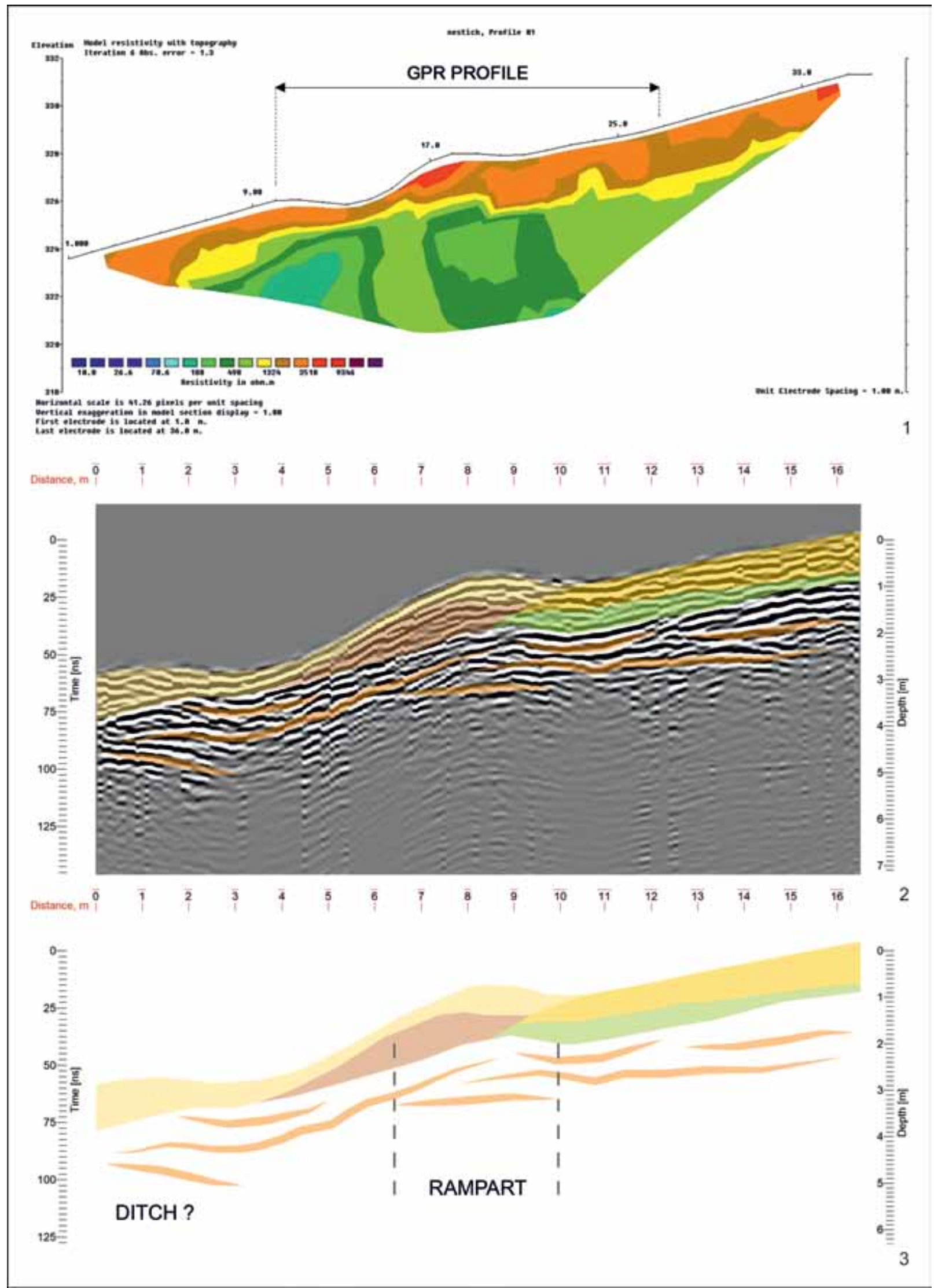

Fig. 10. Rampart at the bailey II. (profile 1). 1 - the resulting ERT measurement profile (Schlumberger configuration); 2 - vertical time/depth GPR cut (500 MHz central frequency antenna); 3 - interpretation plan of GPR profile. 


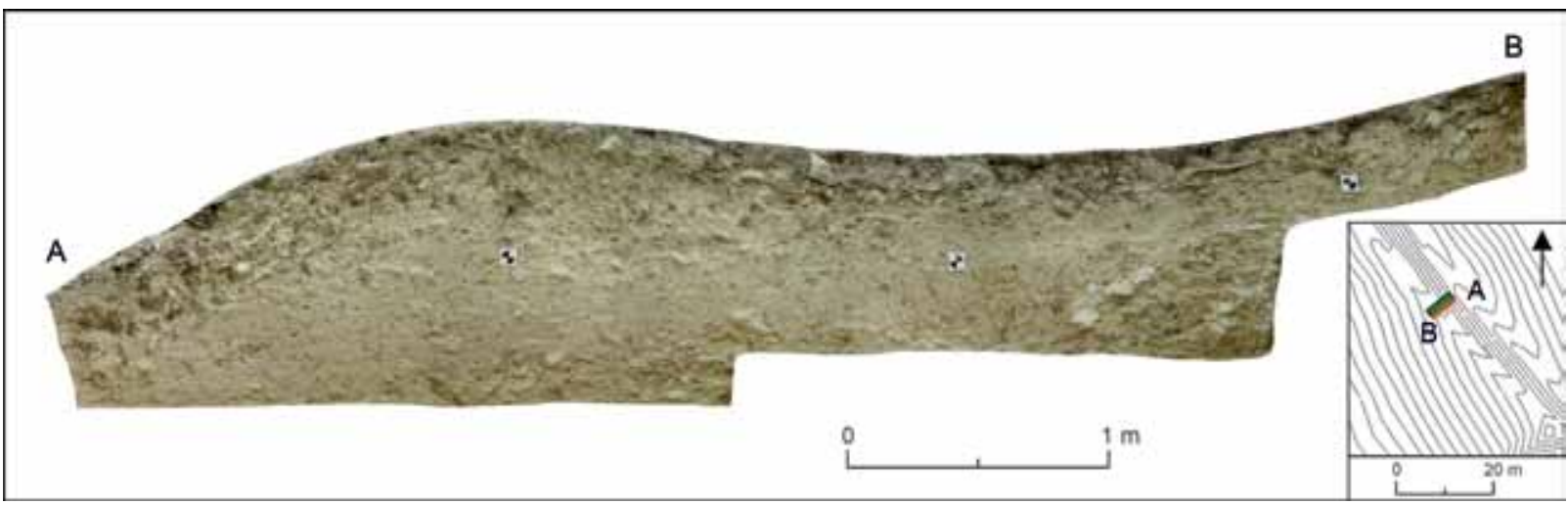

Fig. 11. Bailey II, rampart. Southeast profile of probe XV (photogrammetry L. Soročinová).

both located close to surface. This indicated that the ditch itself is filled with less contrastive material than its surroundings - for example only with clay.

Several horizontal layers can be recognized on the vertical time/depth sections (Fig. 10). The most interesting seem to be the formations inside the rampart body itself, which we can put into perspective with its inner structure. The rampart itself appears to be covered by a few dozens of centimetres of a thick clay layer on the outside. On the inside, two more distinct - probably also clay - layers adhere to the wall. Below them, there is a more significant layer of a convex shape. It is possible that this is a backfill of a recessed object that has not been detected in the area measurement. Inside the rampart body, there are no significant anomalies visible on the radargram that could indicate remains of the front stone wall or other inner construction. The results of the GPR measurement might indicate that the fortification of bailey II was only a simple rampart without any inner construction elements. The ditch was also not very noticeable in the measurements.

The results of the ERT measurement confirmed the results of the GPR research, that is, a simple internal rampart construction (Fig. 10). In the upper part of the outer half of the rampart higher values of resistance were measured. This is probably the result of a bigger amount of stone debris present in the area. Overall, however, the investigated rampart is formed by a backfill from the upper layer of sediment, most likely coming from a ditch.

At the site of the geophysical measurements in the rampart of bailey II, archaeological research which confirmed the observations was subsequently carried out. It turned out that the rampart consists of clay soil excavated mainly from the outer ditch. During this research we did not capture the structure, perhaps it was provided with a simple palisade on the surface (?) or rather a stake fence with spacing and first intertwined with branches or possibly covered with boards/beams. However, we did not detect any trace of them. It seems that the rampart was not meant for a longer more intensive defence. It is believed that lighter fortifications were used more for defending the field camp than for the long-term defense of the fortress (Sláma 1981, 283). It is visibly different from the massive fortification of the acropolis and bailey I. Probe XV not only failed to capture the construction of the rampart but also to obtain any archaeological material that could be used for its dating. Only one set of embers was found during the field research. Preliminary and uncertain, this youngest rampart can be dated back to the second half of the $9^{\text {th }}$ and to the beginning of the $10^{\text {th }}$ century (Fig. 11).

\section{THE QUESTION OF SETTLEMENT ACTIVITIES ON THE HILLFORT AND THEIR CHARACTER BASED ON THE RESULTS OF MAGNETIC RESEARCH}

Regarding the presence of archaeological objects from the early medieval period, it must be said that in mountainous terrain, the possibility of their identification, unlike in lowland environment, is limited due to stony clay-granite bedrock and also due to the presence of a significant number of stones in the cultural layer. The non-significant filling of some objects is also rather problematic. On the hillfort in Svätý Jur, the objects are best documented in the acropolis area where they were captured in the form of recessed rectangular/oval remnants of above-ground buildings - log homes. In one case, 

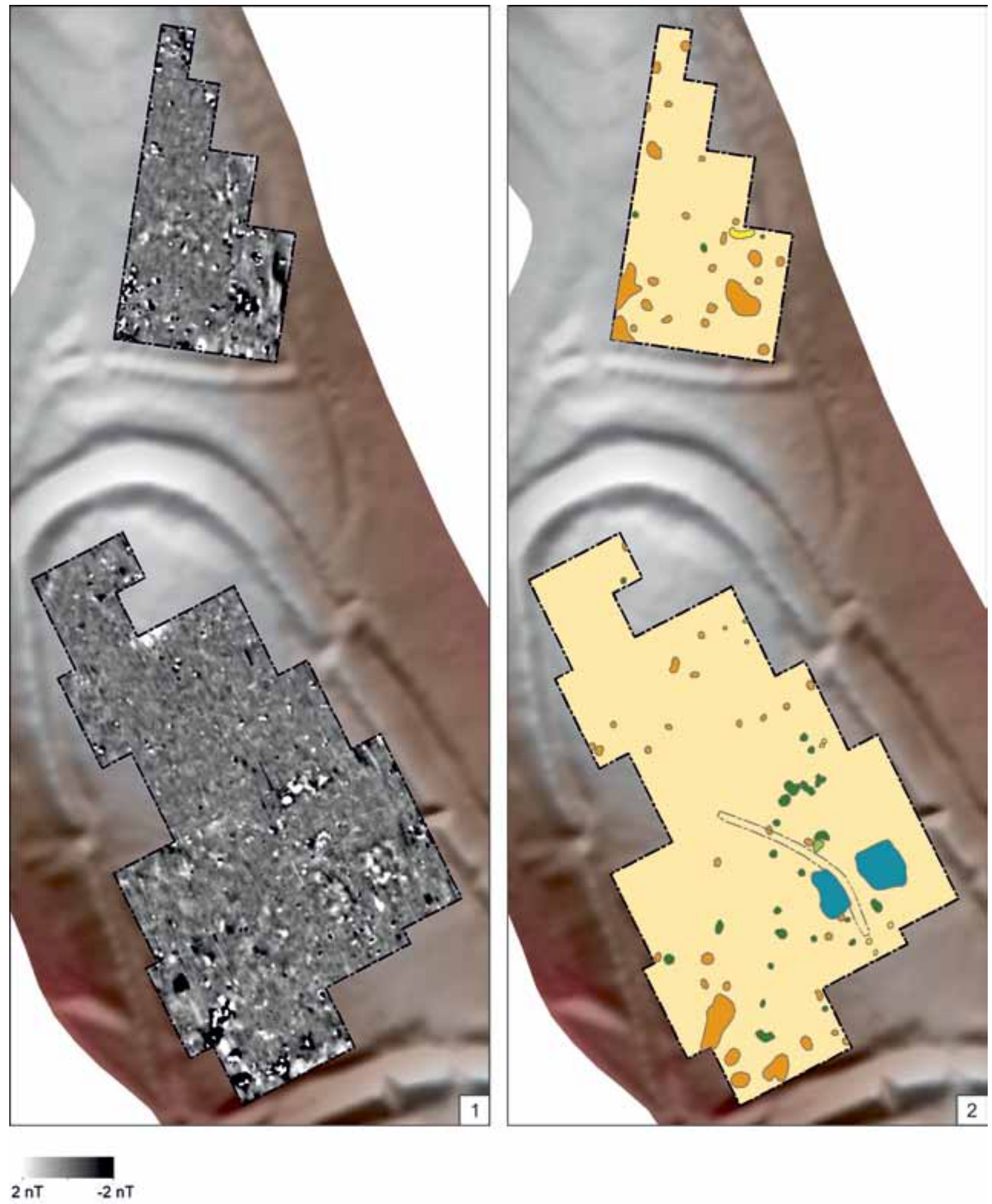

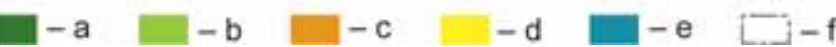


the above-ground object was captured as a remainder of the dry-laid log base. Recessed outbreaks also point to the presence of dwellings. A special group of recessed objects are oval so-called "commercial buildings", whose smaller dimensions indicate the function of some kind of refrigerator. One such object lay in contact with the above-mentioned building on a stone foundation. Rare findings are the remains of stake pits from wooden structures. In one case, L. Kraskovská's stake pits were captured at intervals in one line, apparently as part of the fencing on top of the acropolis. A special group is represented by production facilities characterized by irregular and shallow depressions with findings of numerous blacksmith slags and in the second case with evidence of jewel and glass - crafting activities. The deep circular, stone-lined pit, which probably served as a water tank at bailey I may also be dated back to the early medieval period (Kraskovská 1963, 72, 75, 76, 79, 80, 88-91; Vavák 2019b, 72-75). The presence of objects from the early medieval period at the site is indirectly indicated by the concentrations of ceramic and other findings in the probes, but also by solitary metal objects obtained with the help of metal detectors. The aim of geophysical survey was to provide new knowledge about settlement at the hillfort.

Magnetometry is the most suitable geophysical method for resolving issues related to settlement activities as it is able to explore large areas in a short time and identify a wide range of archaeological features. On sites of the early medieval hillforts we can locate all types of recessed objects such as fences, fireplaces, production objects or even layers by the means of magnetic prospection. Another advantage of magnetometric research is the ability to point to areas where various specific activities were performed. We are talking, for example, about craft activities that have left behind scattered processed material or areas that formerly served as waste sites. Traces of such specific activities are often situated just below the surface and can be easily overlooked during archaeological research. Therefore, it is necessary to anticipate them in advance and magnetic research combined with detailed detector research can give important indications about their occurrence in advance.

A negative factor in the exploration of hillforts situated in mountainous environments is the variable geological subsoil which can significantly affect the overall measurement results. The difficult terrain and often dense forest are also disadvantages which may prevent continuous exploration of complete areas. In this regard, the conditions at Svätý Jur were quite good. The lush vegetation in the area of the main castle is the only factor that we can consider as limiting. It was the reason why only one small area of $110 \mathrm{~m}^{2}$ was examined. It covers the space archaeologically researched in 2007 - before the geophysical measurement - which captured jewellers' workshop within the shallow probe XIV. The small dimensions of the examined area do not allow deeper reflections on the significance of the detected magnetic anomalies. In addition to the area of archaeological research, which showed slightly lower magnetic values than its surroundings, six other anomalous manifestations were recorded. Three of them can be clearly identified as magnetic dipoles, which are an expression of the presence of iron objects of recent origin. The three remaining anomalies can be tentatively identified as potential archaeological objects. One of them is located directly in the unfinished area of the archaeological research. The second is located north of the research area. The last structure is located about $4.5 \mathrm{~m}$ southeast of the research, at the edge of the magnetic survey area. The function or dating of each object is unknown to us. They could be archaeological features of settlement character - settlement pits. Based on the presence of settlement objects documented by archaeological research as well as geophysical research we can assume that the area of the main castle in which our research activities were directed was relatively heavily populated. However, due to the limited scope of the survey, any in-depth consideration must be ruled out. The found objects could perhaps be part of the mentioned jeweller's workshop. Future research can clarify this situation.

More detailed information on the settlement of the site was provided by geophysical prospection at the bailey (Fig. 12). Almost the entirety of bailey I has been researched. The only parts left unresearched were border areas in the north, east, and south. The total researched area exceeded 1 ha. The results of magnetometric measurement correspond to difficult terrain conditions. The wooded and sloping terrain resulted in a partly fragmented magnetogram. Despite that, we managed to find several anomalies within the researched area. Disturbing elements include anomalies with high magnetic values located all over the area of the bailey with the highest concentration at its southern tip. Some of these anomalies can be of archaeological origin but it is more likely that these are mainly recent iron artefacts.

We have also registered anomalies which can be described as potential archaeological features (Fig. 12). In total, nearly thirty such structures were recorded. Most of them are located in the eastern part of the bailey which is adjacent to the main castle. These are structures with irregular to round and 
oval ground plans and dimensions of 1 to $12 \mathrm{~m}^{2}$. Their dating and functions remain unknown to us. It could be different archaeological features of settlement character - dwellings, or economic or production buildings. Magnetically insignificant anomalies scattered throughout the exploration area could also be examined as archaeological objects. However, their further determination is very questionable. In the north-eastern part of the bailey there were also two areas with increased magnetic values which could represent anthropogenically conditioned layers. However, the pedological or geological nature of these structures cannot be excluded either. The linear structure from the central part of the bailey is a recent forest trail.

The findings of geophysical research correspond with the results of archaeological research. L'. Kraskovská presented the most intense traces of early medieval settlement on bailey I near the ramparts of the main castle and proved it by the findings of ceramics, the cultural layer as well as the excavated recessed objects themselves. Medieval ceramic material is also mentioned in the western part of the bailey but there is no longer a cultural layer and there are no recessed objects (Kraskovská 1963, 70, 71). Unlike during previous research, the current research managed to capture it at the top of the bailey in two small probes even though the discovered recessed objects (farm object and stake pit) were difficult to identify (Vavák 2019b, 72, 73). The geophysical research can miss these things completely. However, our view of the overall picture of the settlement in the first bailey does not change significantly. Especially the eastern part of the fortified settlement, which adjoins to the inner rampart of the hillfort, was more intensely populated. The remainder of the bailey was likely to be populated only to a lesser extent or there were settlement activities that left no trace in the form of significant magnetic anomalies.

Geophysical research of bailey II covered its eastern part. Total measured area reached about $0.3 \mathrm{ha}$. The results of the research are significantly influenced by the presence of recent disturbing sources. These are various iron objects scattered all over the area of the bailey with the highest concentration in its southern part. The presence of archaeological objects is unclear. Only three magnetic anomalies can be considered potential archaeological features. These could be smaller settlement pits without dating or specifying their function. As in the previous area on the bailey I we could search for other archaeological objects behind magnetically insignificant anomalies. Overall, however, the space seems to be populated only very sporadically. This result corresponds to our new knowledge. The presence of isolated findings indirectly points to anthropogenic activities in the area of bailey II, however, no objects have been recorded by archaeological methods. In the past, L. Kraskovská researched the bailey with probe XVI which contained only a fraction of the high medieval ceramic pipeline (Kraskovska 1963, 88). Recent research has so far focused on the cross-section of the fortifications, reaching into the inner area of the bailey. Quite modest archaeological finds are also collected, of which only a small part belongs to the early medieval period. Early medieval ceramics are absent completely (Vavák 2019b, 58).

\section{FINAL DISCUSSION}

So far, our knowledge of the settlement of the hillfort in Svätý Jur and its fortifications has been based almost exclusively on the knowledge gained through archaeological research. The geophysical survey of the site thus significantly complements the set of existing knowledge. New evidence of settlement activities at the bailey has been provided by detailed magnetic research. Due to dense vegetation, the survey of the main castle was carried out only to a very limited extent and will remain a challenge to be taken up in the future. GPR and ERT surveys provided information about the structure of the ramparts. The past and present archaeological research, which enabled us to correlate the measured data, provided an important aid in interpreting the collected data.

To date, there is no comprehensive study in the Central European area that would focus on the properties of individual types of early medieval fortifications and their manifestation in geophysical data. The basic building material used for the fortifications were clay and wood, in many cases supplemented with stone. Today, at places of such as fortifications we find dykes, which are often only a secondary manifestation of the destruction of the original ramparts. It is the geophysical survey that can significantly help to determine what form of fortification it was originally and to contribute to the identification of stone and wooden construction elements of the ramparts.

The findings of ceramics inside the ramparts and ditches prove the dating of the fort in Svätý Jur to the early medieval period, namely from the $9^{\text {th }}$ century to the first half of the $10^{\text {th }}$ century (Kraskovská 1963, 89-92, 97-102). Contemporary archaeological research puts the focus of the most intensive use of 
the location in the second half of the $9^{\text {th }}$ century, with an overlap into the first half of the $10^{\text {th }}$ century. The preserved form of the ramparts belongs to that period. However, the origins of early medieval use of the location are older, dating back to the $8^{\text {th }}$ century (Vavák 2019b, 34, 43, 51, 52, 136).

When categorizing early medieval fortifications in Central Europe, we can rely on the classification of R. Procházka, which distinguishes two basic groups of fortifications: simple and composed of several elements (Procházka 2009, 10-18, fig. 1). The first one includes a ditch, rampart and a palisade. The second type is represented by a combined wall consisting of wood, clay and sometimes stone elements which can be combined and interconnected. At the Svätý Jur hillfort we can see both types of fortifications. The main castle and bailey I were protected by massive walls, in one case with a grate construction and in the other with a stake construction holding wooden beams. They were built of clay and stone extracted from the ditch area. The front side was protected by a stone wall, the rear sides were probably both wooden. Bailey II, on the other hand, was only protected by a simple rampart on which a wooden palisade could stand. This is evidenced by archaeological research and is also fully supported by the latest geophysical research.

From the imaginary duel of GPR vs. ERT, the ERT came out victorious. The recorded ERT results offer a surprisingly detailed picture of the internal structure of the ramparts and ditch fillings. In general, two main layers can be recognized on the fortification based on the value of the electrical resistance in the measured profiles: The top layer with electrical resistance values of $1000 \Omega \mathrm{m}$ and more is made up of material consisting of stone debris and soil with greater porosity. Across most of the area, below this layer there is a second one with resistance values of 100 to $1000 \Omega \mathrm{m}$, which is interpreted as a more compact layer consisting of an aluminium substrate and rocks with increased humidity.

The preserved fortification of the main castle has the most compact internal structure. The outer ditch and the inner recess both extend into the bedrock. This way, a large amount of stone was extracted, which was subsequently used for the construction of the wall. This is manifested in higher resistance values in the ERT results. It is a homogeneous unit with a solid compact structure in its central part and on the frontal side of the rampart, which are probably a manifestation of the rich representation of stone rubble in the wall filling and destruction of the front stone wall. We cannot fully exclude any other origin. According to archaeological research conducted by L'. Kraskovská $(1963,86,87)$, the core of the mound could be formed by sintered clay, which may form a compact object with low water content. However, further verification work would be needed to confirm this hypothesis.

The rampart at bailey I shows lower resistance values which can be interpreted as an expression of the remains of a structure made from wood and clay with fewer stones than in the acropolis. Higher resistance values on the outer side of the rampart again indicate the presence of a stone wall. The ERT measurements of the small wall surrounding bailey II do not show any structural elements.

The results of GPR measurements did not show a very differentiated picture of the internal structure of the walls. To some extent, this is also related to our inability to interpret the collected data. Numerous inhomogeneities in the rampart bodies point to different building materials, different intensity of their use, as well as the state of preservation or destruction of the original walls. Nevertheless, it was possible to at least prove the difference in the construction between the walls of the acropolis and bailey I compared to the fortification of bailey II. The ditch fillings were quite distinctly visible on the radargram.

We have also gathered similar results at other researched sites. During the campaign when the fortifications in Svätý Jur were geophysically examined, a total of ten early medieval hillforts in southwestern Slovakia and south Moravia were subjected to similar research. The results of these measurements will be published in a separate comparative study. But we can already claim that the range of results achieved on individual ramparts is well above expectations. By combining individual methods, several structural elements have been identified in detail in several ramparts. With the methods of ERT and GPR we have detected the original levels of the terrain, the stone and clay cores of the ramparts, the extent of the destruction of the stone walls as well as the character and depth of the outer ditches. Surveys of fortifications pointed to significant differences in the used building material, technical design, as well as the current preservation of the walls. From the point of view of geophysical measurement results the hillfort at Svätý Jur is most similar to hillfort Bojná. Both exhibit high electrical resistance values as well as significant inhomogeneities in the GPR survey. Stone was a very significant building material there. On the other hand, there are fortifications such as Bíňa (Henning/Ruttkay 2011, 273-275) and Dolní Věstonice - Vysoká Zahrada (Novotný 1982), where the fortifications were built mostly of clay and wood, which is shown by the results of both geophysical methods. 
Magnetic research brought new knowledge about the settlement at the site. When using classical archaeological methods, it is difficult to solve problems related to the structure and character of the settlement. Area research in different parts of the site would be necessary. Research has only been conducted at two locations in the territorial core of Great Moravia: Mikulčice and Břeclav-Pohansko. Despite many years of research, the overall character and building intensity as well as the functional division of the castle areas remain unclear at other sites. The same applies for the Neštich hillfort. So far, the early medieval settlement there is only documented by a smaller number of objects. We do not have a complete picture of its intensity and structure. From the analysis of the archaeological situations excavated, it appears that log houses with an open fireplace or a stove were built as dwellings on the hillfort (Kraskovská 1963, 90, 91; Vavák 2019b, 71-75). Non-recessed buildings with a minimum of remains always leave a difficult challenge for field archaeological research. Geophysical research is literally blind when trying to record them, and the only detectable components are heating devices, which can indicate the presence of an archaeological feature. However, without archaeological research, we cannot determine whether they are separate fireplaces and furnaces or heating devices in the interiors of undeveloped buildings.

Based on archaeological research, the most intensive settlements can be expected on the acropolis of the hillfort. However, due to dense vegetation, the geophysical survey could only be carried out in a very limited form and did not yield any substantial findings. More detailed information on the settlement of the site was obtained at baileys I and II. It turned out that bailey I was heavily populated in the eastern part, which is adjacent to the main castle. However, these findings will still need to be verified. Thanks to the latest archaeological research anthropogenic activities were also registered in the western part of the bailey. Bailey II could have been populated to a small extent or there were buildings that did not leave any significant traces behind. The absence of ceramics and other significant archaeological findings in conjunction with the almost negative results of geophysical research point to the specific use of the enclosed bailey II as a multifunctional space for example in community gatherings, market management, or temporary animal housing (Vavák 2019b, 111, 136).

The dating of individual structures is problematic. Particularly the area of the main castle shows traces of settlement activities from other periods besides early medieval settlement. An important component is ceramic material from the older Iron Age. The recessed Hallstatt hut directly demonstrates settlement at the location in that period (Kraskovská 1963, 73-76, fig. 3). Archaeological features discovered in the geophysical survey point to the existence of settlement at the site, but their chronological classification remains questionable. We are not confident about the dating of the detected structures and we can only refer to the results of earlier and current archaeological research. The correlation of geophysical and archaeological data allows us to consider a more intensive settlement of the main castle both in the early prehistoric period and in the early medieval period. The site was also used intensively in the high medieval period and part of the documented objects could also belong in here chronologically. However, most of the structures located near the inner rampart in the eastern part of bailey I could be related to the surface findings of the ceramic material and the earlier results of L. Kraskovská's $(1963,70,71,86)$ research and thus to the medieval period. Sporadic traces of settlement in bailey II remain without indication.

We see efforts to extend the knowledge of settlement by comparing archaeological sources and geophysical results in several archaeological sites in the area of south-western Slovakia and south Moravia. Geophysical research took place in large parts of the hillforts. These include Bojná, Břeclav-Pohansko, Majcichov, Mikulčice, Pobedim or Pružina (Henning/Eyub/Ruttkay 2007; Kováčová/Kovár/Milo 2015; Milo/ Dresler/Macháček 2011; Pieta/Ruttkay 2006; Ruttkay et al. 2006). Evidence of settlement appears to be quite diverse. This is partly caused by different field conditions and the scope of the research. At the same time, this fact also points to the diversity that is related to the original use of the sites and which we have to take into account when assessing individual forts.

We can say with certainty that sites such as Bojná, Břeclav-Pohansko and Mikulčice were central to the running of Great Moravia. This is evidenced by rich find complexes as well as dense settlement recorded in both archaeological research and geophysical surveys (Křivánek 2005; Macháček 2007; Milo/ Dresler/Macháček 2011; Pieta/Ruttkay 2006; Poláček/Marek 2005). The significance of the other sites is not clear to us; based on previous research we can say these were centres of regional importance.

Pobedim and Majcichov are the only two early medieval hillforts in the Central Danubian Region which were fully explored by geophysical methods together even with their nearest surroundings. This 
therefore offers the opportunity to trace spatial relationships within individual sectors of these hillforts. To a limited extent, they can also be compared with the hillfort in Svätý Jur. The hillfort in Pobedim has two parts - the transverse inner wall divides it into the main castle in the position of "Hradište" and the so-called bailey in the position of "Podhradište". Archaeological research of D. Bialeková has documented dense medieval and prehistoric settlements (Bialeková 1978; 1996). The total area examined by archaeological methods is approximately 1 ha. Magnetic measurement, which is still ongoing, covered in 2019 the entire area of the fort and its wide background covering approximately 120 ha. The large number of magnetic anomalies prove intensive settlement of the site, especially in the area of the main castle (Henning/Eyub/Ruttkay 2007, fig. 1). It is not possible to determine the chronological identity of individual objects through geophysical measurements. Most of the objects are not related to the hillfort settlement. They are remnants of prehistoric settlement which used the original elevated terrain configuration here. Fewer archaeological features were recorded in the bailey. Based on their location we can assume that a large part of them belong to the same historic period as the hillfort. In analogy to the settlement in Svätý Jur, they are accumulated mainly in the area near the fortification separating the bailey from the main castle.

The hillfort Majcichov cannot be directly compared with the Svätý Jur hillfort. Magnetic prospection revealed only a few potential features in the inner area of the hillfort. This is because of a younger alluvial layer which covered the original settlement horizon (Fottová/Henning/Ruttkay 2007, 224, 225). This layer acts as a barrier that does not allow individual settlement features to be identified using magnetic survey. We can see a certain similarities at the ditch and probably also at the rampart-encircled bailey which was located to the east of the Majcichov hillfort. As at Svätý Jur, there were features that represent various settlement pits and probably also dwellings and ovens.

Out of the geophysically investigated hillforts, the hillfort in Pružina has similar terrain conditions to the Svätý Jur hillfort. The disadvantage is that there has never been any systematic archaeological research done at Pružina. The fortified settlement is made up of two separate enclosed spaces (Mesciská I and II), which were in their accessible parts geophysically explored, and a large bailey on the southern side, which was not investigated (Kováćová/Kovár/Milo 2015). At the location of Mesciská I, various settlement features could be observed only in the geologically homogeneous central and northern parts of the hillfort. Their number is very low due to the size of the surveyed area. Altogether there were fifteen structures scattered throughout the area. The nature and functional classification of these structures seem to be diverse. We cannot unequivocally comment on the structure of the built-up area. In principle, however, we can assume that the location was not densely populated and by its nature we can compare it with the results of geophysical research of bailey I in Svätý Jur.

The situation appears different at a smaller hillfort at Mesciská II, where concentrations of archaeological features were detected. It can be assumed that this part of the hillfort was mainly used as a residential area. Provided that both hillforts were operating at the same time, we can assume that position II could have been inhabited more densely and continuously, for example in the form of a smaller court, while the larger area I was inhabited only sparsely and seasonally. As in Svätý Jur, there is evidence of different settlement intensity in individual areas of the hillfort separated by fortifications.

The conclusions about the hillfort at Svätý Jur presented in this paper are based on the results of geophysical surveys conducted here in 2018 and 2019. The aim of geophysical prospection was the detection of subsurface structures in an effort to locate areas with potential occurrence of archaeological situations at the hillfort, as well as to define the internal structure of the ramparts and to identify the individual structural elements of the wall. For the most part, it succeeded. Knowledge obtained from earlier archaeological research that took place at the hillfort played an important role in the interpretation of geophysical data. However, a more thorough and reliable evaluation of geophysically measured data will only be possible after at least partial verification by field archaeological research. The archaeological research that has been going on at the hillfort in recent years and will continue in the future will therefore focus on verifying our conclusions. 


\section{BIBLIOGR APHY}

Bialeková 1978

Bialeková 1996

\section{Clark 1990}

Eisner 1928

Eisner 1933

Fottová/Henning/Ruttkay 2007

Gajdoš 1977

Henning/Eyub/Ruttkay 2007

Henning/Ruttkay 2011

Janšák 1929

Kováčová/Kovár/Milo 2015

Kraskovská 1962

Kraskovská 1963

Křivánek 2005

Ludikovský/Hašek/Obr 1978

Macháček 2007

Mareš et al. 1990

Milo/Dresler/Macháček 2011

Novotný 1982

Pašteka et al. 2014

Pieta et al. 2011

Pieta/Ruttkay 2006
D. Bialeková: Výskum a rekonštrukcia fortifikácie na slovanskom hradisku v Pobedime. Slovenská archeológia 26, 1978, 149-177.

D. Bialeková: Der slawische Burgwall von Pobedim (Ein Beitrag zur Lösung chronologischer und gesellschaftlich-historischer Fragen). In: Č. Staňa/L. Poláček (eds.): Frühmittelalterliche Machtzentren in Mitteleuropa. Mehrjährige Grabungen und ihre Auswertung. Symposion Mikulčice, 5.-9. September 1994. Internationale Tagungen in Mikulčice 3. Brno 1996, 141-147.

A. Clark: Seeing Beneath the Soil. Prospecting methods in archaeology. London 1990.

J. Eisner: Prehistorický výzkum na Slovensku a v Podkarpatské Rusi r. 1927. Sborník Muzeálnej slovenskej spoločnosti 22, 1928, 26-40.

J. Eisner: Slovensko v pravěku. Bratislava 1933.

E. Fottová/J. Henning/M. Ruttkay: Archeologický výskum včasnostredovekého hradiska v Majcichove. Archäologische Grabung eines frühmittelaltrelichen Burgwalls in Majcichov. In: K. Pieta/A. Ruttkay/M. Ruttkay (eds.): Bojná. Hospodárske a politické centrum Nitrianskeho kniežatstva. Wirtschaftliches und politisches Zentrum Nitraer Fürstentums. Archaeologia Slovaca Monographiae. Studia 9. Nitra 2007, 217-236.

V. Gajdoš: Výsledky geoyzikálneho prieskumu na niektorých archeologických lokalitách na Slovensku. Geofyzikální prospekce v archeologii. 2. celoštátny seminár archeogeofyziky. Nové Vozokany 1976. Zprávy Československé společnosti archeologické 19, 1977, 115-117.

J. Henning/E. Eyub/M. Ruttkay: Geomagnetic prospecting of the hillfort Pobedim (Slovakia). $7^{\text {th }}$ International Conference on Archaeological Prospection. Študijné zvesti AÚ SAV 41, 2007, 58-59.

J. Henning/M. Ruttkay: Frühmittelalterliche Burgwälle an der mittleren Donau im ostmitteleuropäischen Kontext: Ein deutsch-slowakisches Forschungsprojekt. In: J. Macháček/Š. Ungerman (eds.): Frühgeschichtliche Zentralorte in Mitteleuropa. Studien zur Archäologie Europas 14. Bonn 2011, 259-288.

Š. Janšák: Slovenské hradiská z doby halštatskej. Sborník Muzeálnej slovenskej spoločnosti 23, 1929, 1-33.

L. Kováčová/B. Kovár/P. Milo: Hradisko Pružina-Mesciská a jeho okolie. In: P. Jencík/V. Struhár (eds.): Hradiská - Svedkovia dávnych čias. Zborník odborných príspevkov o hradiskách a ich obyvatel’och. Dolná Mariková 2015, 175-185.

L. Kraskovská: Nálezové správy o výskumoch na slovanskom hradisku v Jure pri Bratislave. Archív SNM. Archeologické múzeum v Bratislave. Bratislava 1962. Unpublished.

L. Kraskovská: Vel'komoravské hradisko v Jure pri Bratislave (výskumy na hradisku). Sborník SNM 57. História 3, 1963, 67-103.

R. Křivánek: Geofyzikální měření na Pohansku u Břeclavi v letech 2000-2002. Archeologické rozhledy 57, 2005, 139-146.

K. Ludikovský/V. Hašek/F. Obr: Geofyzikální výzkum př́ičného valu na slovanském hradisku v Pobedimi. Slovenská archeológia 26, 1978, 185-192.

J. Macháček: Pohansko bei Břeclav. Ein frühmittelalterliches Zentrum als sozialwirtschaftliches System. Studien zur Archäologie Europas 5. Bonn 2007.

S. Mareš/J. Gruntorád/S. Hrách/M. Karous/M. Matolín/J. Skopec/R. Válek: Úvod do užité geofyziky. Praha 1990.

P. Milo/P. Dresler/J. Macháček: Geophysical prospection at the Břeclav-Pohansko stronghold. In: J. Macháček/Š. Ungerman (eds.): Frühgeschichtliche Zentralorte in Mitteleuropa. Studien zur Archäologie Europas 14. Bonn 2011, 79-88.

B. Novotný: K problematice způsobu výstavby opevnění nížinného hradiště Strachotína-Vysoké Zahrady u Dolních Věstonic na Moravě. Archaeologia historica 7, 1982, 325-334.

R. Pašteka/R. Putiška/D. Kušnirák/I. Dostál/I. Murín: Výsledky geofyzikálneho prieskumu (magnetometria, georadar) vybranej časti hradiska Neštich. Záverečná správa. Malokarpatské múzeum v Pezinku. Bratislava 2014. Unpublished.

K. Pieta/J. Haruštiak/M. Jakubčinová/T. Vangl’ová: Výskum včasnostredovekého hradiska Bojná I v rokoch 2007 a 2008. AVANS v roku 2008, 2011, 205-211, 354-356.

K. Pieta/A. Ruttkay: Bojná - mocenské a christianizačné centrum nitrianskeho kniežatstva. In: K. Pieta/A. Ruttkay/M. Ruttkay (eds.): Bojná. Hospodárske a po- 
Poláček/Marek 2005

Procházka 2009

Ruttkay et al. 2006

Sláma 1981

Šalkovský 2015

Tirpák 1977

Tirpák 2005

Tomčíková 1983

Turčan 2000

Vavák 2009

Vavák 2015

Vavák 2019a

Vavák $2019 b$

Waddell/Fenwick/Barton 2009 litické centrum Nitrianskeho kniežatstva. Wirtschaftliches und politisches Zentrum Nitraer Fürstentums. Archaeologia Slovaca Monographiae. Studia 9. Nitra 2006, 21-69.

L. Poláček/O. Marek: Grundlagen der Topographie des Burgwalls von Mikulčice. Die Grabungsflächen 1954-1992. Studien zum Burgwall Mikulčice 7. Brno 2005.

R. Procházka: Vývoj opevňovací techniky na Moravě a v českém Slezku v raném středověku. Spisy Archeologického ústavu AV ČR Brno 38. Brno 2009.

M. Ruttkay/J. Henning/E. Fottová/E. Eyub/P. Milo/J. Tirpák: Archeologický výskum a geofyzikálna prospekcia na včasnostredovekých hradiskách v Majcichove a v Pobedime. In: Ve službách archeologie 7. Brno 2006, 93-112.

J. Sláma: Raně středověká hradiště s částečně opevněným prvním předhradím. Praehistorica 8. Varia archaeologica 2, 1981, 281-284.

P. Šalkovský: Hrady západných Slovanov. Archaeologia Slovaca Monographiae. Fontes 9. Nitra 2015.

J. Tirpák: Prieskum niektorých archeologických lokalít Slovensku. Geofyzikální prospekce v archeologii. 2. celoštátny seminár archeogeofyziky. Nové Vozokany 1976. Zprávy Československé společnosti archeologické 19, 1977, 120-122.

J. Tirpák: Geofyzikálny prieskum - Svätý Jur. Poloha hradisko Neštich. Geofyzikálna správa. Malokarpatské múzeum v Pezinku. Nitra 2005. Unpublished.

K. Tomčíková: Vel'komoravské hradisko v Jure pri Bratislave. AVANS v roku 1982, 1983, 250.

V. Turčan: Príspevok k poznaniu včasnostredovekého osídlenia Sv. Jura pri Bratislave. Zborník SNM 94. Archeológia 10, 2000, 123-136.

J. Vavák: Najstaršie osídlenie Svätého Jura. In: J. Turcsány a kol. (ed.): Svätý Jur 1209-2009. Dejiny písané vínom. Svätý Jur 2009, 13-25.

J. Vavák: Mohutná pevnost' v Malých Karpatoch. Historika - malokarpatský historický občasník 4, 2015, 4-7.

J. Vavák: Pevnost’ vo Svätom Jure. Výskum v rokoch 2015-2018. Historika - malokarpatský historický občasník 8, 2019, 4-9.

J. Vavák: Pevnost' v Malých Karpatoch. Vznik, význam a úloha výšinného centra vo Svätom Jure. Pezinok 2019.

J. Waddell/J. Fenwick/K. Barton: Rathcroghan. Archaeological and geophysical survey in a ritual landscape. Dublin 2009.

\title{
Svätý Jur Neštich - nové poznatky k osídleniu a fortifikácii včasnostredovekého sídla
}

\author{
Peter Milo - Július Vavák - Michal Vágner - Michaela Prištáková - \\ Igor Murín - Tomáš Tencer
}

Súhrn

Hradisko vo Svätom Jure je v literatúre známe ako dôležité sídlo z obdobia včasného stredoveku, datované nálezmi do 9. stor., predovšetkým do jeho druhej polovice. Prvé doklady využívania polohy vo včasnom stredoveku pochádzajú z priebehu 8. stor. Čast pamiatok by mohla patrit do prvej polovice 10. stor. Okrem hlavného hradu elipsovitého tvaru, ktorý sa vyznačuje mohutným opevnením, má hradisko ešte dve chronologicky mladšie predhradia. Celková rozloha opevneného areálu zaberá 8,5 ha. Archeologický výskum tu bol realizovaný už v rokoch 1957-1962, pričom v roku 2006 bol obnovený. Informácie o hustote a štruktúre osídlenia polohy a charaktere pevnostného systému boli napriek tomu relatívne skromné. Nové poznatky sme sa preto pokúsili získat použitím širokého spektra geofyzikálnych prospekčných metód. Vykonané boli merania Elektrickej odporovej tomografie (ERT) a georadarový prieskum (GPR), ktoré sa sústredili na fortifikačné prvky hradiska a plošný magnetický prieskum. Ten sa zameral na vnútorný areál predhradí. Pomocou ERT sme preskúmali tri segmenty fortifikácie hradiska. Georadarový prieskum sa uskutočnil na štyroch miestach opevnenia. Magnetická prospekcia pokryla v rámci troch areálov plochu s výmerou 1,4 ha. Z metodologického hladiska zohrala dôležitú úlohu komparácia geofyzikálnych dát s výsledkami starších archeologických výskumov. 
O vnútornej stavbe hradby na akropole sme mali informácie zo staršieho archeologického výskumu L'. Kraskovskej. Z dokumentovanej archeologickej situácie vyplýva, že konštrukcia valu sa skladala z priečnych trámov, ktoré boli poukladané v štyroch vrstvách nad sebou. Táto konštrukcia bola zasypaná hlinou s prímesou kameňov. I ked' sa nepodarilo nájst' pozdĺžne trámy, môžeme predpokladat', že ide vo včasnom stredoveku o široko rozšírenú roštovú konštrukciu. Z vonkajšej strany bola prepojená s čelným kamenným múrom. Stopy ohňa poukazujú na skutočnost', že opevnenie zaniklo požiarom. Geofyzikálny prieskum sa uskutočnil na severozápadnej strane akropoly. GPR prieskumu sa podarilo identifikovat' výrazné súvrstvia súvisiace s telesom valu a deštruovanou hradbou v jeho dolných partiách. Horizontálne vrstvy v telese valu dokladajú miesta, kde je pôvodná hradba dodnes zachovalá. Výrazné reflexie boli dokumentované aj v priekopách. Napovedajú, že v hradbe je výrazne zastúpený kamenný stavebný materiál. Celkovo však môžeme konštatovat', že výsledky GPR prospekcie nie sú jednoznačné a medzi intaktnou častou hradby, jej deštrukciou a výplňou priekop nie sú zretelné podstatné rozdiely. Väčšiu vypovedaciu hodnotu majú elektrické odporové merania. Celý val sa prejavuje vyššími hodnotami odporu, pričom v jeho centrálnej časti a z frontálnej strany sú anomálie tvorené materiálom s najväčšími nameranými hodnotami odporu (nad $10000 \Omega \mathrm{m}$ ) na lokalite. Takéto vysoké hodnoty poukazujú na bohaté zastúpenie kamenného stavebného materiálu. Dané pozorovanie plne zodpovedá výsledkom archeologického výskumu. Vysoké hodnoty elektrického odporu v telese valu predstavujú kamennú výplň v konštrukcii hradby. Vysoké hodnoty elektrického odporu v dolných partiách frontálnej strany hradby môžeme zasa interpretovat’ ako deštrukciu čelnej kamennej steny opevnenia.

Vnútorná štruktúra valu na predhradí I nám bola tiež čiastočne známa zo staršieho archeologického výskumu. Z nálezovej situácie vyplýva, že opevnenie malo dve fázy. V 1. fáze sa tu nachádzala konštrukcia z kolov, upevnených kameňmi a umiestnených šachovnicovo v dvoch radoch. Koly fixovali trámy, medzi ktorými bola nasypaná zem. Z vonkajšej strany bola kolová konštrukcia spevnená kamenným múrom. Celá hradba mala približne $3 \mathrm{~m}$ hrúbku. Druhá fáza vznikla po zničení 1. fázy, kedy bola plocha zarovnaná a na nej bol nasypaný val zo žltej hliny. Koly boli v tejto fáze umiestnené v štyroch rovnobežných radoch. Predpokladá sa, že medzi nimi boli umiestnené d’alšie drevené prvky zasypané hlinou. Na vonkajšej strane sa opät nachádzala kamenná stena. Hrúbka mladšej hradby bola 4,5-5 m. V rámci geofyzikálneho prieskumu valu predhradia I bola položená otázka, ako sa fortifikácia prejaví v georadarových a ERT dátach, aká bude vypovedacia hodnota meraní a predovšetkým, aký bude rozdiel oproti výsledkom dosiahnutým na vale hlavného hradu. Hlavná pozornost' bola venovaná profilu, ktorý prechádzal cez val a vonkajšiu priekopu na severovýchodnej strane predhradia. Vo výsledkoch georadarových meraní možno sledovat' súvrstvia, ktoré majú súvislost' s vnútorným zložením valu. Bližšie však toto zloženie definovat’ nevieme. Možno len povedat', že na radarograme nie je žiadna výraznejšia anomália, ktorá by poukazovala na prítomnost' zachovalého kamenného múru vo vnútri telesa valu. Dané zistenie korešponduje každopádne s vyššie uvádzanými výsledkami archeologického výskumu. Výsledky ERT meraní zasa dokladajú skutočnost', že priekopy boli využité ako zdroj stavebného materiálu. Ich híbky zasahujú až do kamenistej vrstvy v podloží.

Val vyčleňujúci predhradie II je najmenší a zároveň aj najmladší. Geofyzikálny prieskum sa sústredil na severovýchodný segment valu. Výsledky GPR aj ERT prieskumu nasvedčujú interpretácii, že v prípade opevnenia predhradia II ide o jednoduchý sypaný val bez akýchkolvek vnútorných konštrukčných prvkov. Vel'mi nevýrazne sa v meraniach prejavila aj priekopa. Na mieste geofyzikálnych meraní bol následne uskutočnený archeologický výskum, ktorý dané pozorovania potvrdil. Ukázalo sa, že val nemá žiadnu vnútornú konštrukciu a je tvorený ílovitou zeminou vykopanou najmä z vonkajšej priekopy.

Pri riešení otázok spojených so sídelnými aktivitami je najvhodnejšou geofyzikálnou metódou magnetometria. Najintenzívnejšie osídlenie môžeme na základe doterajších archeologických výskumov očakávat’ na akropole hradiska. Vzhladom na hustú vegetáciu tu však mohol byt’ geofyzikálny prieskum uskutočnený iba vo vel'mi obmedzenej forme a žiadne podstatné zistenia nepriniesol. Podrobnejšie informácie o osídlení lokality sa podarilo získat na predhradiach. Ukázalo sa, že predhradie I bolo intenzívne osídlené predovšetkým vo východnej časti, ktorá sa primyká k hlavnému hradu. Dané zistenie však ešte bude nutné overit'. Antropogénne aktivity totiž registrujeme vd’aka posledným archeologickým výskumom aj v západnej časti predhradia. Predhradie II mohlo byt’ osídlené v malej miere alebo tu stáli stavby, ktoré po sebe nezanechali výraznejšie stopy. Absencia črepov a iných výrazných archeologických nálezov poukazuje, v spojení s takmer negatívnymi výsledkami geofyzikálneho výskumu, na osobitné využitie ohradeného areálu predhradia II.

Obr. 1. Poloha hradiska Svätý Jur-Neštich (podkladové dáta geoportal.sk). Červená čiara - val.

Obr. 2. Lokalizácia archeologických výskumov na ploche hradiska. Legenda: a - výskum J. Vavák; b - výskum L. Kraskovská; c - výskum L. Kraskovská (neistá lokalizácia).

Obr. 3. Lokalizácia GPR a ERT profilov a plochy magnetického prieskumu na pláne hradiska. Legenda: a - GPR profily; b-ERT profily; $\mathrm{c}$ - magnetometria.

Obr. 4. Val na akropole. 1 - západný profil rezu valom; 2 - východný profil rezu valom (upravené podla Kraskovská 1962; 1963, obr. 9). Legenda: a - hnedá premiešaná zemina; b - uhlík; c - kameň; d - červeno prepálená zemina; e - tmavá zemina; $\mathrm{f}$ - spálené drevo.

Obr. 5. Val na akropole (profil 3). 1 - výsledný profil merania ERT (Schlumbergerova konfigurácia); 2 - vertikálny 
časový/hĺbkový GPR rez (anténa o centrálnej frekvencii $500 \mathrm{MHz}$ ); 3 - interpretačný plán GPR profilu.

Obr. 6. Val na predhradí I. Pôdorysná situácia zaznamenaná pri archeologickom výskume - staršia a mladšia fáza fortifikácie (upravené podla Kraskovská 1963, obr. 7; 8). Legenda: a - uhlík; b - kameň, mladšia fáza; c - kameň, staršia fáza; d - kolová jama, mladšia fáza; e - kolová jama, staršia fáza; $\mathrm{f}$ - vrstva; $\mathrm{g}$ - sonda.

Obr. 7. Val na predhradí I (profil 2). 1 - výsledný profil merania ERT (Schlumbergerova konfigurácia); 2 - vertikálny časový/hĺbkový GPR rez (anténa o centrálnej frekvencii $500 \mathrm{MHz}$ ); 3 - interpretačný plán GPR profilu.

Obr. 8. Val na predhradí I (profil 4). 1 - vertikálny časový/híbkový GPR rez (anténa o centrálnej frekvencii 500 MHz); 2 - interpretačný plán GPR profilu.

Obr. 9. Val na predhradí II (plocha 1). 1 - výsledné horizontálne časové/hĺbkové rezy získané meraním s anténou o centrálnej frekvencii $500 \mathrm{MHz}$ (vytvorené v GPR Slice); 2 - interpretačný plán nameraných dát. Legenda: a začiatok; b - vrstevnice; c - anomálie; d - GPR meranie.

Obr. 10. Val na predhradí II (profil 1). 1 - výsledný profil merania ERT (Schlumbergerova konfigurácia); 2 - vertikálny časový/hllbkový GPR rez (anténa o centrálnej frekvencii $500 \mathrm{MHz}$ ); 3 - interpretačný plán GPR profilu.

Obr. 11. Val na predhradí II. Juhovýchodný profil sondy XV (fotogrametria L. Soročinová).

Obr. 12. Predhradia I a II. Magnetogram a jeho interpretácia. Legenda: a - archeologická štruktúra; b - archeologická štruktúra (?); c - recentná štruktúra; d - recentná štruktúra (?); e - geológia (?); f - chodník.

Translated by Boleslav Žemlík

doc. Dr. Phil. Peter Milo

Ústav archeologie a muzeologie

Filozofická fakulta

Masarykova univerzita

Arna Nováka 1

CZ - 60200 Brno

milop@post.sk

Mgr. Michal Vágner, PhD.

Ústav archeologie a muzeologie

Filozofická fakulta

Masarykova univerzita

Arna Nováka 1

CZ - 60200 Brno

vagnermichal@mail.muni.cz

Mgr. Igor Murín, PhD.

Ústav archeologie a muzeologie

Filozofická fakulta

Masarykova univerzita

Arna Nováka 1

CZ - 60200 Brno

igor.m@post.sk
PhDr. Július Vavák, PhD.

Malokarpatské múzeum v Pezinku

M. R. Štefánika 4

SK - 90201 Pezinok

julius.vavak@muzeumpezinok.sk

Mgr. Michaela Prištáková

Ústav archeologie a muzeologie

Filozofická fakulta

Masarykova univerzita

Arna Nováka 1

CZ - 60200 Brno

pristakova@mail.muni.cz

Mgr. Tomáš Tencer, PhD

Ústav archeologie a muzeologie

Filozofická fakulta

Masarykova univerzita

Arna Nováka 1

CZ - 60200 Brno

tencer@mail.muni.cz 